\title{
Presence of Arsenic in Potential Sources of Drinking Water Supply Located in a Mineralized and Mined Area of the Sierra Madre Oriental in Mexico
}

\author{
Victor Manuel Escot-Espinoza ${ }^{1}$ (D), Yann Rene Ramos-Arroyo ${ }^{2}$, Isabel Lázaro ${ }^{1,3}$ (D), Isidro Montes-Avila ${ }^{1}$, \\ Leticia Carrizalez-Yañez ${ }^{4}$ and Roberto Briones-Gallardo $1,3, *$ (D)
}

1 Facultad de Ingeniería, Universidad Autónoma de San Luis Potosí, Av. Dr. Manuel Nava 304, San Luis Potosí 78210, Mexico; victor.escot@alumnos.uaslp.edu.mx (V.M.E.-E.); ilazaro@uaslp.mx (I.L.); isidro.montes@uaslp.mx (I.M.-A.)

2 Departamento de Ingeniería Geomática e Hidráulica, Universidad de Guanajuato, Av. Juárez 77, Zona Centro, Guanajuato 36000, Mexico; yr.ramos@ugto.mx

3 Instituto de Metalurgia, Universidad Autónoma de San Luis Potosí, Sierra Leona 550, San Luis Potosí 78210, Mexico

4 CIAAS/CIACYT, Facultad de Medicina, Universidad Autónoma de San Luis Potosí, Sierra Leona 550, San Luis Potosí 78210, Mexico; letcay@uaslp.mx

* Correspondence: briones@uaslp.mx; Tel.: +52-444-8261450

\section{check for} updates

Citation: Escot-Espinoza, V.M.; Ramos-Arroyo, Y.R.; Lázaro, I.; Montes-Avila, I.; Carrizalez-Yañez, L.; Briones-Gallardo, R. Presence of Arsenic in Potential Sources of Drinking Water Supply Located in a Mineralized and Mined Area of the Sierra Madre Oriental in Mexico. Toxics 2021, 9, 307. https://doi.org/ $10.3390 /$ toxics 9110307

Academic Editor: Pierre-Marie Badot

Received: 15 October 2021

Accepted: 10 November 2021

Published: 15 November 2021

Publisher's Note: MDPI stays neutral with regard to jurisdictional claims in published maps and institutional affiliations.

Copyright: (c) 2021 by the authors Licensee MDPI, Basel, Switzerland. This article is an open access article distributed under the terms and conditions of the Creative Commons Attribution (CC BY) license (https:/ / creativecommons.org/licenses/by/ $4.0 /)$.

\begin{abstract}
Mine wastes from the La Aurora mine in the state of Guanajuato were generated by the flotation process and placed in four tailing dumps on the local stream while the plant operated. Given that these wastes contain toxic elements, it is important to establish their impact on the quality of several surrounding natural sources of water that are considered potential drinking water supplies. This study identified four water source types, in which the contents of arsenic (As), mercury ( $\mathrm{Hg}$ ), and thallium ( $\mathrm{Tl}$ ) were exceeded, according to international guideline values for drinking water quality. The first type of aqueous sample corresponded to leachates produced by rainwater infiltration in tailings and water-mineral waste interactions. The second type corresponded to surface water along the Xichú and La Laja Streams, and the third and fourth types involved two groundwater well samples and spring samples, respectively. The Chiquito Stream was used as a reference area that had not been impacted by the mine wastes. The isotopic signatures associated with $\delta^{34} S_{\text {sulfate }}$ and $\delta^{18} \mathrm{O}_{\text {sulfate }}$ compositions from the El Ojo de Agua spring are similar to those of the Santa María River and are different from those of the mine waste leachates. This study shows evidence of the presence of As in the El Ojo de Agua spring, which results from dissolution of secondary mineral phases that were produced by alteration of the mine wastes, which then migrated along the Xichú Stream system until reaching the spring. These As-bearing fine particles are prone to dissolution when in contact with this water source. Principal component analysis revealed that the observed As, Tl, and $\mathrm{Hg}$ can be attributed to weathering of the mine wastes. However, the results suggest that a natural contribution of these elements could be associated with rainwater-igneous rock interactions.
\end{abstract}

Keywords: mine wastes; secondary mineral phases; arsenic; dissolution mechanism; spring water quality

\section{Introduction}

For many years, mining and metallurgical activities have generated hundreds of millions of tons of waste. The types of generated waste include the tailings from several operations, such as flotation, amalgamation, cyanidation, or refining processes, as well as slags and dust particles from smelting furnaces [1]. Worldwide, tailings dumps are mainly composed of particles of different sizes that have been placed at sites adjacent to the mine processing area and represent many abandoned mine waste dumps (AMWDs) [2-5]. These AMWDs generally lack pollution control measures and are typically piled near abandoned 
mines. Waste dumps resulting from skarn-type mineral processing are characterized by pyrite $(\mathrm{Py})$, marcasite $(\mathrm{Mrc})$, galena $(\mathrm{Gn})$, sphalerite $(\mathrm{Sp})$, chalcopyrite $(\mathrm{Ccp})$, covellite $(\mathrm{Cv})$, arsenopyrite (Apy), argentite (Arg), aluminosilicates (Als), calcite (Cal), and other carbonate-rich rocks [6]. In the absence of adequate control and containment measures, these wastes undergo alteration processes (physicochemical or biological) when exposed to environmental conditions (precipitation, flood, evaporation, desiccation, solar radiation, drought, and wind) $[4,7,8]$. Some of these AMWDs that are rich in Pyrite produce acid mine drainage (AMD) via sulfide oxidation processes, and the produced leachates are typically highly acidic and have high concentrations of potentially toxic elements (PTEs), which primarily include arsenic (As), lead $(\mathrm{Pb})$, mercury $(\mathrm{Hg})$, and thallium $(\mathrm{Tl})$ [1,7,9-11]. Hence, AMD neutralization generates new secondary mineral phases (SMPs) that contain large quantities of PTEs that are either adsorbed, precipitated, or coprecipitated [10]. Some secondary phases reported as products of AMD neutralization are melanterite (Mel), copiapite (Cpt), coquimbite (Cqm), ferricopiapite (Fcpp), schwertmannite (Swm), gypsum (Gy), anglesite (Ang), K-jarosite (K-Jrs), beudantite (Bdt), scorodite (Scr), ferrihydrite (Fhy), goethite (Gth), hematite (He), and lepidocrocite (Lpd) [4]. Some of the reactions that produce SMPs under such conditions have been described by several authors [1,7,12-15].

The main hypothesis of this study, which focuses on how PTEs are produced and impact water bodies, supposes that-depending on local climatological conditions and the topographical positions of the dumps-the new SMPs have the potential to react with the environment and remain in the waste dumps, thereby forming a stable cemented crust. However, solid fragments of these SMPs could disseminate and be incorporated into stream sediments. Once in the stream bed, SMPs have the potential to migrate downstream by hydric erosion, accumulate in low-energy areas such as floodplains, and continue their travels until they reach different bodies of water, thereby affecting the quality of the stream surface and groundwater. Consequently, the accumulation of As in water sources originates from geogenic or anthropogenic processes [16,17].

The finer PTE-bearing particles can move via suspension in surface water and infiltrate through the porous spaces of stream sediments $[18,19]$. Skarn deposits have ubiquitous occurrences of arsenopyrite [6]. In the environment, As can be found in two oxidation states, $\mathrm{As}(\mathrm{V})$ or As(III) (as oxyanions, arsenates, or arsenites). As(V) species are predominant under oxidizing conditions, while As(III) species predominate under reducing conditions, and their equilibrium speciation depends on the $\mathrm{pH}$ and the redox potential $\left(\mathrm{E}_{\mathrm{H}}\right)$ of the system $[9,20,21]$. Due to the slow oxidation-reduction rate of these species, inorganic chemical species of both $\mathrm{As}(\mathrm{III})$ and $\mathrm{As}(\mathrm{V})$ can coexist simultaneously. The $\mathrm{As}(\mathrm{V})$ leached from AMWDs can be attenuated via adsorption, precipitation, or coprecipitation involving iron oxides, iron oxide-hydroxides $(\mathrm{IOH})$, and iron oxide-hydroxy-sulfates $\left(\mathrm{IOH}-\mathrm{SO}_{4}{ }^{2-}\right)$, such as ferrihydrite, goethite, and Jrs, among other SMPs [1,4,7].

Conversely, the presence of $\mathrm{Hg}$ is not exclusively associated with skarn deposits, as it is possible to find contents as high as 5000 and $9000 \mu \mathrm{g} / \mathrm{kg}$ in igneous and alkaline rocks, respectively [22,23]. High concentrations of $\mathrm{Hg}$ in surface waters (up to $100 \mathrm{ng} / \mathrm{L}$ ) have been reported when natural waters are in contact with rocks or sediments with a high content of this element [24]. Recently, pollution of water with Tl, associated with AMD, has been reported. Thallium pollution in the public water supply system in a location in Italy was identified and associated with the draining of the spring throughout a mineralized pyritous zone with a high content of this element $[25,26]$.

The region studied in this work is in a rugged, mountainous zone in the Sierra Gorda of Guanajuato, which has faced several challenges related to developing infrastructure that favors water accessibility. Based on a volume of $31.5 \mathrm{Mm}^{3}$, that drains from springs annually from these sources [27], the drinking water supply for the Sierra Gorda marginalized communities can potentially be sustained. Therefore, it is important to determine the water quality and to describe the geochemical processes that control it. Hence, this work focuses on identifying the presence of $\mathrm{As}, \mathrm{Hg}$, and $\mathrm{Tl}$ and evaluating their impact on natural springs, well groundwater, and surface water. In addition, it is important to 
discern whether the presence of these elements is natural or associated with the leachates coming from the AMWDs at the now inactive mine known as La Aurora in the Xichú mining district (XMD).

\section{Study Site Description}

\subsection{Geological and Hydrological Context}

The XMD is in the Sierra Madre Oriental physiographic region in the subprovince of Karst-Huasteco in the Zimapán Basin (Figure 1a). According to the topographic map of the study area, the altitudes range from 2640 to $800 \mathrm{~m}$ above sea level (m.a.s.1.), with very abrupt slopes $[27,28]$. According to the Köeppen-Geiger climate classification, the study area is classified as Bsh, which corresponds to hot semi-arid (sttepe) climate [29].

From registers of a meteorological station situated $7 \mathrm{~km}$ southwest of the Xichu tailings in the same hydrological basin, it was found that in this zone predominates orographic rainfall that discharges as storms of high intensity. A climatograph (Figure S1), constructed with the average of monthly data from the period 1951-2015 [30], shows that the period of rains is between spring and summer and the average annual precipitation is $575.5 \mathrm{~mm}$, characterized by a midsummer drought or heatwave, during July-September. Almost every year, a storm of $20 \mathrm{~mm}$ in one hour occurs, and the maximum of daily precipitation ever registered is $158 \mathrm{~mm}$ [31]. All the materials in this basin are exposed to the effect of erosivity of rains. Particularly, tailings deposits can be eroded. The erosion effect depends on the layer crust formed on the surface of the mine wastes.

The AMWDs were placed on the Xichú Stream hillside over the Soyatal-Mezcala Formation (KtmCz-Lu). Quartz monzonitic intrusions (TpaQMz) are distributed in this formation close to the La Aurora and El Cristo mines, heading NW-SE and affecting the terrigenous sediments of the Soyatal-Mezcala Formation. This gives rise to two types of mineralized alterations: the Xichú alteration and the Tijeras-Peña Bernal-Lucero-San Diego alteration. The mineralized bodies of the Xichú alteration are in a contact halo shape, forming exoskarns with structures such as veins, mantles, and irregular chimneys [32]. According to the Mexican geological survey [32], the skarn mineralized bodies exploited in La Aurora mine have their origin from hydrothermal solutions at moderate-high temperatures, which are characteristic of epithermal and mesothermal deposits [33]. The TijerasPeña Bernal-Lucero-San Diego alteration surrounds the La Aurora mine on its NW and SE flanks and is housed in the El Abra (Kat-Cz) and Soyatal-Mezcala Formations (Figure 1a). This alteration is mainly composed of iron oxides produced by the oxidation of pyriterites, which are found filling fractures [32].

The XMD is in the hydrological region of the Santa María Bajo River subbasin (RH26Cj) that is part of the Panuco River, which discharges at the Gulf of Mexico.

Due to the geological characteristics of this zone, three types of aquifers can be found: fractured mediums associated with Tertiary rhyolites, granular mediums in recent alluvial valleys, and a karstic medium in the limestones of the El Abra Formation [27]. This formation is a geological structure characterized by high permeability, due to karstic conditions that, combined with faults and fractures, promote the discharge of various springs in the study area.

The Chiquito Stream is considered a reference area that has not been impacted by the AMWDs from the XMD. The background values of $\mathrm{As}, \mathrm{Hg}$, and $\mathrm{Tl}$ concentrations in the water within the study area were established based on a sample of the Chiquito Stream (location R1, Figure 1), which is located close to the El Alamo community at 1634 m.a.s.l., which is $8.5 \mathrm{~km}$ upstream of the area with mine waste dumps and has a confluence with the Xichú Stream after the Misión de Santa Rosa (Figure 1a). This stream outcrop is in a geological zone that favors fractures in the igneous porphyritic rhyoliteporphyritic dacite (ToRP-DaP) (Figure 1a). This type of volcanic rock can be associated with hydrothermal alteration and can contribute to the presence of toxic elements such as As, $\mathrm{Hg}$, and $\mathrm{Tl}[8,22,24,25]$. A second reference area that has also not been impacted by AMWDs is connected to four springs that discharge close to the Palomas community 
at 1300 m.a.s.l. and $23 \mathrm{~km}$ to the northeast of the AMWDs from the XMD (Figure 1d), without any apparent hydraulic connection. This is a zone where springs and rainwater collection are a source of water and is geologically characterized by the contact between Cretaceous El Abra limestones and Jurassic shales of the Las Trancas Formation (Figure 1d). However, the use of spring water could be compromised due to the presence of $\mathrm{As}, \mathrm{Hg}$, and Tl. The limit for As and $\mathrm{Hg}$ concentrations were established by the World Health Organization (WHO) at 10 and $6 \mu \mathrm{g} / \mathrm{L}$, respectively [35], and at 25 and $1 \mu \mathrm{g} / \mathrm{L}$, respectively, by the Mexican normative [36]. With respect to Tl, the Environmental Protection Agency (EPA) has established a limit of $13 \mu \mathrm{g} / \mathrm{L}$ for the protection of human health [37].
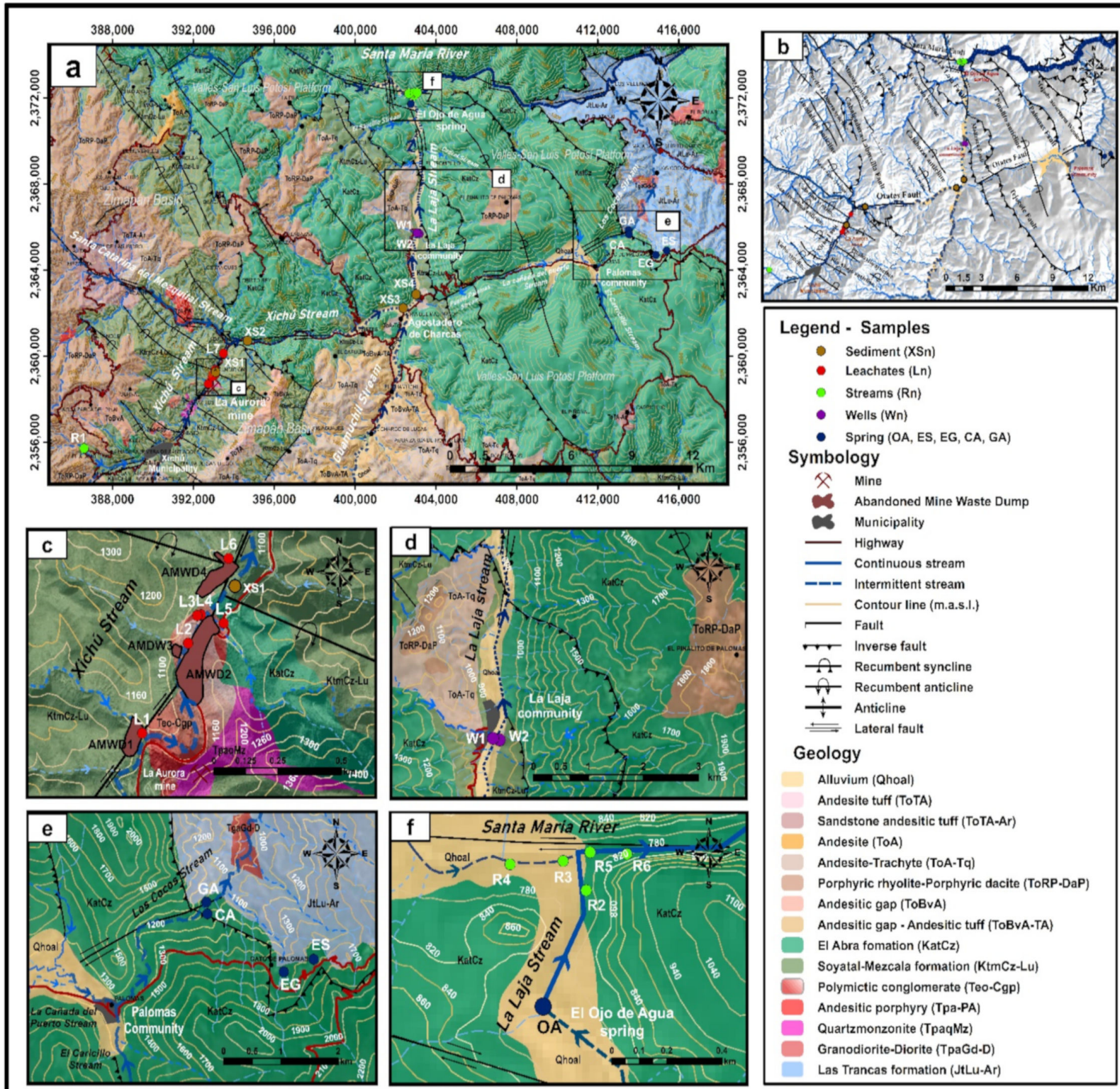

Andesite (ToA)

Andesite-Trachyte (ToA-Tq)

orphyric rhyolite-Porphyric dacite (ToRP-DaP)

Soyatal-Mezcala formation (KtmCz-Lu)

Polymictic conglomerate (Teo-Cgp)

Andesitic porphyry (Tpa-PA)

nzonite (TpaqMz)

Figure 1. (a) Map of the study area and location of the collection of water and sediment samples. (b) Geological structural map representing the main fault, orography, and hydrography context. (c) Close-up view of the wastes area. (d) Close-up view of the La Laja community area. (e) Close-up view of the Palomas community area. (f) Close-up view of the confluence between the El Ojo de Agua spring and the Santa María River. The labels identify the sampling points by the type of stream body or the stream sediments, or both (based on data from the geological maps of Arredondo-Mendoza et al. [32] and González-Ramos and Rodríguez-Moreno [34]). 
The hydrogeology in this zone has not been thoroughly studied until now. To begin to develop a hydrological model, it is necessary to know that this region is located between two Cretaceous paleobasins: the Zimapan Basin to the west and the Valles-San Luis Potosí platform to the east [38]. The lithologies of both basins consist primarily of platform limestones with interbedded sandstones, and both have Jurassic shales of the Las Trancas Formation as the hydrogeological basement.

At the location where the Xichú Stream receives the Adjuntas Creek, As concentrations in the stream sediments reportedly range from $\sim 13$ to $40 \mathrm{mg} / \mathrm{kg}$ [32,34]. Approximately $10 \mathrm{~km}$ beyond this point is the beginning of the alluvial valley, with an accumulation of fine particles overlying gravel and sands. Due to the high permeability of this coarse material, the groundwater in local flow systems can circulate. The El Ojo de Agua spring is located on the La Laja Stream bed $7 \mathrm{~km}$ away from the La Laja community (Figure 1a) and is parallel to the La Laja lateral fault. The flow of this spring has been estimated to be between 850 and $1000 \mathrm{~L} / \mathrm{s}[27,39]$. This spring is influenced by both the Las Trancas Formation, which acts as the hydrogeological basement (locally mineralized), and the El Abra Formation. In this area, rainwater infiltrates the karstified material of the El Abra Formation [40], which could give rise to two groundwater wells used by the La Laja community or even the El Ojo de Agua spring (Figure 1e).

\subsection{Origin and Characteristics of Abandoned Mine Waste Dumps}

In the XMD, six abandoned mines have been recorded: La Aurora, Don Pedro, Lucero, El Cristo, Casa Blanca, and La Tijera [33]. The AMWDs evaluated in this study are located $4 \mathrm{~km}$ NE of the community of Xichú, Guanajuato, Mexico. There are a few reports that describe the mining residues associated with the activities of these mines, but these reports do not examine either the presence of PTEs in the neighboring soils or the Xichú Stream sediments that are derived from mine waste oxidation [27,41,42]. In fact, only one study has evaluated the environmental impact of the PTEs present in leachate from mine waste and the presence of these PTEs in some springs in the region [11]. Even though the La Aurora mine had multiple operational periods, this study considered the AMWDs generated during the period between 1935 and 1957.

Activities during this period involved the processing of skarn-type polymetallic sulfides that contained galena $(3.5 \% \mathrm{~Pb})$, sphalerite $(5 \% \mathrm{Zn})$, chalcopyrite $(2 \% \mathrm{Cu})$, Arg (which contains 250-750 g As/t), and pyrite [33]. The AMWDs are constituted by sulfide mineral phases with a pyrite-galena-sphalerite-chalcopyrite-covellite-hematite paragenetic sequence [43]. The ore mineral deposits that were processed were emplaced in limestone and sedimentary rocks [43-45]. After 1957, the mine and mine tailings were abandoned without any containment or prevention measures to mitigate their oxidation. CarrilloChávez et al. [41] evaluated the concentrations of the four AMWDs present on the banks of the Xichú Stream, finding As concentrations from 1753 to $62,302 \mathrm{mg} / \mathrm{kg}$, as well as $\mathrm{Pb}$ concentrations (from 670 to $17,426 \mathrm{mg} / \mathrm{kg}$ ), but they did not report $\mathrm{Hg}$ and $\mathrm{Tl}$ values. Also, they indicated that $\mathrm{As}$ and $\mathrm{Pb}$ pollution from wastes is attenuated in situ due to sorption, precipitation, or coprecipitation reactions in the dumps. Ramos-Arroyo et al. [27] estimated that the volumes of two sulfide-rich mine waste deposits located on the banks of the Xichú Stream were $41,973.55 \mathrm{~m}^{3}$ and $189,934.93 \mathrm{~m}^{3}$. These authors suggested that approximately 1 million tons of waste was generated from the flotation process during the recovery of lead $(\mathrm{Pb})$, zinc $(\mathrm{Zn})$, copper $(\mathrm{Cu})$, and silver $(\mathrm{Ag})$, and they suggested that the As release rate from AMWDs of the La Aurora tailings to the Xichú Stream bed is $2 \mathrm{~kg} /$ year.

Understanding $\mathrm{As}, \mathrm{Hg}$, and $\mathrm{Tl}$ dispersion and release mechanisms toward potential sources of water constitutes a crucial part of the contributions of this research. Likewise, it is important to associate springs with different groundwater flow systems to determine potential vulnerabilities to changes in weather and the presence of mineralization and mine wastes [46].

Geochemical maps from the Mexican Geological Survey (SGM) allow the identification of the average and maximum concentrations of As in this area: the average basal As 
concentration is $\sim 8 \pm 6 \mathrm{mg} / \mathrm{kg}(n=215)$ in stream sediments, and the maximum As concentration ranges from 106 to $135 \mathrm{mg} / \mathrm{kg}$ [32,34]. The SGM does not report $\mathrm{Hg}$ or $\mathrm{Tl}$ concentrations in stream sediments in these geochemical maps.

In this work, evidence of the impact of $\mathrm{As}, \mathrm{Hg}, \mathrm{Tl}$, and $\mathrm{Pb}$ on water bodies is provided. It has been verified through field inspection that detachment of SMPs occurs in large fragments due to hydric erosion and that these fragments are then incorporated into the channel of the Xichú Stream. These events show the physical entry of the contaminated fragments and the dispersion of PTEs bearing solid particles into the channel of the Xichú Stream. Additionally, rainstorm events allow these materials to move away from the source and migrate to low-energy areas, eventually impacting the studied water bodies, affecting their quality, and putting the water security of the area at risk [8].

\section{Materials and Methods}

\subsection{Water Sampling and Chemical Analysis}

The map in Figure 1 shows the physiographic provinces of the study area and the spatial location of the different collected samples. Different sources of water samples were collected and grouped as (1) leachates, (2) well water, (3) river water, and (4) spring water (Table 1).

Table 1. Geographical location, type, and physical condition of the aqueous and solid samples collected in the study area.

\begin{tabular}{|c|c|c|c|c|c|}
\hline \multirow{2}{*}{$\begin{array}{c}\text { Label } \\
\text { Sample }\end{array}$} & \multicolumn{2}{|c|}{ UTM Coordinates } & \multirow{2}{*}{$\begin{array}{l}\text { Altitude } \\
\text { (m.a.s.1.) }\end{array}$} & \multirow{2}{*}{$\begin{array}{l}\text { Type of } \\
\text { Sample }\end{array}$} & \multirow{2}{*}{ Description of the Sampling Site } \\
\hline & $\mathrm{X}$ & $\mathbf{Y}$ & & & \\
\hline L1 & 392,742 & $2,358,724$ & 1120 & Leachates & $\begin{array}{l}\text { Water sample from handmade rainwater channel for local } \\
\text { irrigation, located on the lateral wall of AMWD1. }\end{array}$ \\
\hline L2 & 392,922 & $2,359,056$ & 1104 & Leachates & $\begin{array}{c}\text { Leachate water sample produced by water infiltration through } \\
\text { the AMWD2. }\end{array}$ \\
\hline L3 & 392,958 & $2,359,158$ & 1118 & Leachates & $\begin{array}{l}\text { Water sample collected from the Xichú Stream, impacted by the } \\
\text { runoff of leachate water from the walls of AMWD4. }\end{array}$ \\
\hline $\mathrm{L} 4$ & 392,972 & $2,359,161$ & 1083 & Leachates & $\begin{array}{l}\text { Water sample collected from the Xichú Stream, impacted by the } \\
\text { runoff of water leachate from the lateral walls of AMWD2. }\end{array}$ \\
\hline L5 & 393,062 & $2,359,130$ & 1140 & Leachates & $\begin{array}{l}\text { Mine water sample collected from the mineralized zone of La } \\
\text { Aurora, located in the La Fundición community. }\end{array}$ \\
\hline L6 & 393,081 & $2,359,369$ & 1100 & Leachates & $\begin{array}{l}\text { Water sample from handmade rainwater channel for local } \\
\text { irrigation, located on the lateral wall of AMWD4. }\end{array}$ \\
\hline L7 & 393,483 & $2,360,138$ & 1041 & Leachates & $\begin{array}{l}\text { Water sample from the Xichú Stream, impacted by leachate } \\
\text { runoff located } 850 \mathrm{~m} \text { downstream from AMWD4. }\end{array}$ \\
\hline W1 & 403,068 & $2,365,735$ & 846 & $\begin{array}{l}\text { Water } \\
\text { well }\end{array}$ & Water sample from drinking water well of the La Laja community. \\
\hline W2 & 413,488 & $2,365,725$ & 849 & $\begin{array}{l}\text { Water } \\
\text { well }\end{array}$ & $\begin{array}{l}\text { Water sample from handmade drinking water well of the La Laja } \\
\text { community, at } 100 \mathrm{~m} \text { from W1 sample. }\end{array}$ \\
\hline $\mathrm{R} 1$ & 386,596 & $2,355,721$ & 1610 & Streams & $\begin{array}{l}\text { Water sample from the Chiquito Stream located close to El Alamo } \\
\text { community at } 1634 \text { m.a.s.l. at } 8.5 \mathrm{~km} \text { upstream from AMWD1. }\end{array}$ \\
\hline $\mathrm{R} 2$ & 402,933 & $2,372,130$ & 761 & Streams & $\begin{array}{c}\text { Water sample collected on the La Laja stream, located at } 380 \mathrm{~m} \\
\text { downstream from the El Ojo de Agua spring. }\end{array}$ \\
\hline R3 & 402,846 & $2,372,215$ & 765 & Streams & $\begin{array}{l}\text { Water sample from the Santa María River, located } 100 \mathrm{~m} \text { before its } \\
\text { confluence with the La Laja Stream. }\end{array}$ \\
\hline $\mathrm{R} 4$ & 402,614 & $2,372,157$ & 763 & Streams & $\begin{array}{l}\text { Water sample from the Santa María River, located } 250 \mathrm{~m} \text { before its } \\
\text { confluence with the La Laja stream. }\end{array}$ \\
\hline R5 & 402,929 & $2,372,254$ & 754 & Streams & $\begin{array}{l}\text { Water sample from the Santa María River, located } 100 \mathrm{~m} \text { after its } \\
\text { confluence with the La Laja stream. }\end{array}$ \\
\hline R6 & 403,063 & $2,372,233$ & 759 & Streams & $\begin{array}{l}\text { Water sample from the Santa María River, located } 200 \mathrm{~m} \text { after its } \\
\text { confluence with the La Laja stream. }\end{array}$ \\
\hline OA & 402,758 & $2,371,729$ & 756 & Spring & $\begin{array}{l}\text { Water sample from the El Ojo de Agua Spring on the La Laja } \\
\text { Stream bed. }\end{array}$ \\
\hline GA & 413,520 & $2,365,858$ & 1029 & Spring & Water sample from Guayaba Agria spring. \\
\hline CA & 413,539 & $2,365,666$ & 1163 & Spring & Water sample from El Carricillito spring. \\
\hline EG & 414,872 & $2,364,717$ & 1436 & Spring & Water sample from El Gato spring. \\
\hline ES & 415,394 & $2,364,923$ & 1550 & Spring & Water sample from El Sarro spring. \\
\hline
\end{tabular}


Table 1. Cont.

\begin{tabular}{|c|c|c|c|c|c|}
\hline \multirow{2}{*}{$\begin{array}{c}\text { Label } \\
\text { Sample }\end{array}$} & \multicolumn{2}{|c|}{ UTM Coordinates } & \multirow{2}{*}{$\begin{array}{l}\text { Altitude } \\
\text { (m.a.s.l.) }\end{array}$} & \multirow{2}{*}{$\begin{array}{l}\text { Type of } \\
\text { Sample }\end{array}$} & \multirow{2}{*}{ Description of the Sampling Site } \\
\hline & $\mathrm{X}$ & $\mathbf{Y}$ & & & \\
\hline AMWD4 & 393,085 & $2,359,291$ & 1110 & Waste & Solid samples of wastes taken from AMWD4. \\
\hline XS1 & 393,106 & $2,359,266$ & 1103 & Sediment & $\begin{array}{l}\text { Stream sediment from Xichú River impacted by fine particles } \\
\text { generated by mineral secondary phases, precipitated chemically } \\
\text { on the walls of the mining waste deposit. Sample located in the } \\
\text { lower part of the AMWD } 4 .\end{array}$ \\
\hline XS2 & 394,683 & $2,360,714$ & 1040 & Sediment & $\begin{array}{l}\text { Surface layer of sediments from the Xichú stream in the low } \\
\text { energy zone, } 2.6 \mathrm{~km} \text { downstream from the AMWD4. }\end{array}$ \\
\hline XS3 & 402,605 & $2,362,269$ & 895 & Sediment & $\begin{array}{l}\text { Superficial layer of stream sediments from Xichú Stream in the } \\
\text { zone of low energy and produced by its drying, before its } \\
\text { confluence with the Guamuchil stream. }\end{array}$ \\
\hline XS4 & 403,015 & $2,362,875$ & 860 & Sediment & $\begin{array}{l}\text { Superficial layer of stream sediments from Xichú Stream in the } \\
\text { zone of low energy and produced by its drying, after its } \\
\text { confluence with the Guamuchil stream. }\end{array}$ \\
\hline
\end{tabular}

Water samples were taken from the same site in three clean polypropylene containers. The determination of several parameters was performed as follows: (1) physicochemical parameters (temperature, $\mathrm{pH}, \mathrm{E}_{\mathrm{H}}$, electrical conductivity $(\mathrm{EC})$, and dissolved oxygen (DO)); (2) total major and trace element concentrations $(\mathrm{Na}, \mathrm{Mg}, \mathrm{K}, \mathrm{Ca}, \mathrm{Fe}, \mathrm{Mn}, \mathrm{Al}, \mathrm{As}, \mathrm{Pb}, \mathrm{Cu}$, $\mathrm{Zn}, \mathrm{Sr}, \mathrm{Mn}, \mathrm{Hg}$, and $\mathrm{Tl})$; and (3) anion concentrations $\left(\mathrm{HCO}_{3}{ }^{-}, \mathrm{CO}_{3}{ }^{2-}, \mathrm{Cl}^{-}, \mathrm{SO}_{4}{ }^{2-}\right.$, and $\mathrm{NO}_{3}{ }^{-}$). All samples were filtered using $0.45 \mu \mathrm{m}$ nylon filters prior to their respective analyses. Physicochemical parameters were determined in the field with multiparameter equipment (HANNA HI9828 with a $\mathrm{Ag} / \mathrm{AgCl}$ reference electrode). All total major and trace element analyses were performed on the filtered samples to $0.2 \mu \mathrm{m}$ using nylon filters and were acidified with $37 \% \mathrm{HNO}_{3}$ using inductively coupled plasma atomic emission spectrometry (ICP-AES iCAP 7000, Thermo Scientific, Cambridge, United Kingdom. The As concentration was determined using a graphite furnace, coupled with an atomic absorption spectrometer (EAA-HG, Analyst 200 PinAAcle 900T, Perkin Elmer, Whaltham, United States). The reference material, NIST-1643f, was used as an internal control with an As concentration of $57.4 \pm 0.4 \mu \mathrm{g} / \mathrm{L}$ and a recovery percentage of $99.6 \%$. Anion determination was performed on filtered samples that were not acidified using anion exchange chromatography equipment (Dionex ICS-5000+, Thermo Scientific, San Jose, United State). In liquid samples, the alkalinity was determined in $100 \mathrm{~mL}$ of aqueous sample and $0.02 \mathrm{~N}$ $\mathrm{H}_{2} \mathrm{SO}_{4}$ for acid titration using phenolphthalein and methyl orange indicators, following Method 2320-A Alkalinity from the Standard methods [47]. The isotopic composition of $\delta^{34} \mathrm{~S}_{\text {sulfate }} \%$ and $\delta^{18} \mathrm{O}_{\text {sulfate }} \%$ in $\mathrm{SO}_{4}{ }^{2-}$ ions was determined at the Environmental Isotopy Laboratory of the Department of Geosciences at the University of Arizona. The stable isotope of $\delta^{34} \mathrm{~S}_{\text {sulfate }} \%$ in $\mathrm{SO}_{4}{ }^{2-}$ ions was reported with respect to the Devil's Canyon Troilite (CDT) standard, while $\delta^{18} \mathrm{O}_{\text {sulfate }} \%$ in $\mathrm{SO}_{4}{ }^{2-}$ ions was reported with respect to Vienna standard mean ocean water (VSMOW).

\subsection{Waste and Sediment Mineralogical Characterization}

Six solid waste samples were recovered from AMWDs, three of them from the terrace of the deposit and the other three from the sidewalls where leachate drainage was observed. Additionally, four recent stream sediment samples were collected within an area of $1 \mathrm{~m}^{2}$ and at a depth of $5 \mathrm{~cm}$. All sediment samples were collected in zones of low energy in the dry streambed at the time of sampling (XS1-XS4). All solid samples (wastes and sediments) were free of vegetal matter, sieved in the field using $2 \mathrm{~mm}$ mesh and transported to the laboratory in clean polyethylene bags. Subsequently, the samples were dried at room temperature for $72 \mathrm{~h}$. The As concentrations in stream sediments were determined by $\mathrm{X}$-ray fluorescence (XRF) using a portable analyzer (INNO-X DELTA, Olympus DPO-2000-CC). A mineralogical characterization of the stream sediments was accomplished by $\mathrm{X}$-ray diffraction (XRD) using X-ray diffractometer (D8 Advance, Brucker, Berlin, Germany). 
XRD analysis was performed on samples with a particle size $<44 \mu \mathrm{m}$ using the powder diffraction method with a source of $\mathrm{Cu} \mathrm{K} \alpha$ radiation between 10 and $90^{\circ}$, a $2 \theta$ variation of $0.02^{\circ}$ and an analysis total time of $21 \mathrm{~min}$. X-ray diffraction pattern interpretation of stream sediments was performed by comparing the spectra identified with Joint Committee on Powder Diffraction Standards (JCPDS) cards from the International Center for Diffraction Data (ICDD). XRD analysis identified the mineral phases that make up the matrix or the PTE carrier phases, or both. To identify the presence of primary and As-bearing SMPs, mineralogical characterization was complemented with scanning electron microscopy (SEM) using a Philips XL30 microscope equipped with an energy dispersive X-ray spectrometer (EDAX DX460), to perform quantitative chemical analyses.

\subsection{Hydrogeochemical Analysis}

The major anion and cation concentrations in the water samples were used to generate Stiff and Piper diagrams using AquaChem 3.7 software (Waterloo hydrogeologic, Waterloo, $\mathrm{ON}$, Canada). Since EC is considered to be the main chemical marker related to pyrite oxidation and AMD production [48], a Piper diagram was constructed by considering the EC value to normalize the size of the icon of the represented samples (Figure 2). For each aqueous solution sample, the charge balance was calculated using the WATEQ4F database in PHREEQC v. 2.15 [49], and the charge imbalance (CI) was calculated according to Nordstrom et al. [50]. Likewise, the saturation indices (SI) of mineral phases identified by XRD in the mine wastes were calculated using PHREEQC with the Thermoddem database [51]. Relationships between the physicochemical variables analyzed in the water samples were evaluated using Pearson's correlation tests and principal component analysis (PCA). Pearson's correlation was used to evaluate the relationship among physicochemical parameters, cations, and anions that were quantified in the leachates, streams, wells, and spring water samples in the study area. The correlation was also used to suggest the reactions driving the presence of major and trace elements in solution for all water samples. Table S1 shows that red and blue numbers have significant positive and negative correlations, respectively $(p<0.05)$. In the PCA, the eigenvalues and variances were determined to establish principal components (PCs). With PCA diagrams, it is possible to observe the interaction between the variables and samples; a grouping of samples suggests a common source [52].

Prior to PCA, all data measured in aqueous solution were transformed using a power function, $\mathrm{b}_{\mathrm{ij}}=\mathrm{x}_{\mathrm{ij}} \mathrm{p}$, with $p=0.5$. Additionally, two inclusion criteria were used for the chemical and physicochemical variables: first, their values should be above the detection limit of the chemical method used, and second, the value of the variable should be at least $20 \%$ of samples. In addition, $\mathrm{Fe}, \mathrm{Cu}, \mathrm{Pb}$, and $\mathrm{Zn}$ concentrations were incorporated and considered geochemical markers of mine waste weathering.

For the interpretation of the PCA results, both the eigenvectors of the first and second components were projected, as well as the graphic representation of the sample types, to identify the trends of the water flows. In this study, a PCA value was calculated for each of the aqueous samples [53]. In this case, up to five main components were considered, representing $82 \%$ of the covariance of samples. Hence, the dimension of the system was reduced from 25 to 5 transformed variables that correspond to the $Z_{\text {isk }}$ scores. The calculation of the $Z_{\text {isk }}$ scores was carried out with Equation (1) for each sample, as follows:

$$
\mathrm{Z}_{\text {isk }}=\sum_{\mathrm{j}}^{\mathrm{m}} \mathrm{Ev}_{\mathrm{ij}} \times \operatorname{var}_{\mathrm{j}}^{1 / 2},
$$

where $\mathrm{Ev}_{\mathrm{ij}}$ and var $_{\mathrm{j}}$ represent the values of the eigenvectors and the variables transformed to the square root power function, respectively.

With the value of the $Z_{\text {isk }}$ scores, it was possible to calculate the PCA value for each of the samples $\left(\mathrm{PCA}_{\mathrm{sk}}\right)$ according to Equation (2), where $\mathrm{Eg}_{\mathrm{i}}$ represents the eigenvalue from the i-esime eigenvector.

$$
\mathrm{PCA}_{\mathrm{sk}}=\sum_{\mathrm{i}}^{\mathrm{m}=5} \mathrm{Z}_{\text {isk }} \times \mathrm{Eg}_{\mathrm{i}} /\left(\sum_{\mathrm{j}}^{\mathrm{n}=5} \mathrm{Eg}_{\mathrm{j}}\right.
$$


In this work, PCA value ranges were proposed to establish the water quality indices for each water sample by associating the calculated value with the degree of contamination [54]. The water quality indices and the proposed stratification of PCA value ranges are as follows: (1) uncontaminated [PCA < 1.63]; (2) slightly-moderately contaminated [1.63 < PCA < 2.45]; (3) moderately-strongly contaminated [2.45 < PCA < 3.26]; (4) strongly contaminated [3.26 < PCA < 4.9]; and (5) extremely contaminated [PCA $>4.9$ ].

The PCA value ranges were established considering the gap between the maximum and minimum values (without one outlier sample L3) and divided by three. The result of this operation is considered a base value to classify samples as uncontaminated if the PCA is below such a base value. Subsequently, the next ranges were established as 1.5, 2, and 3 times the base value.

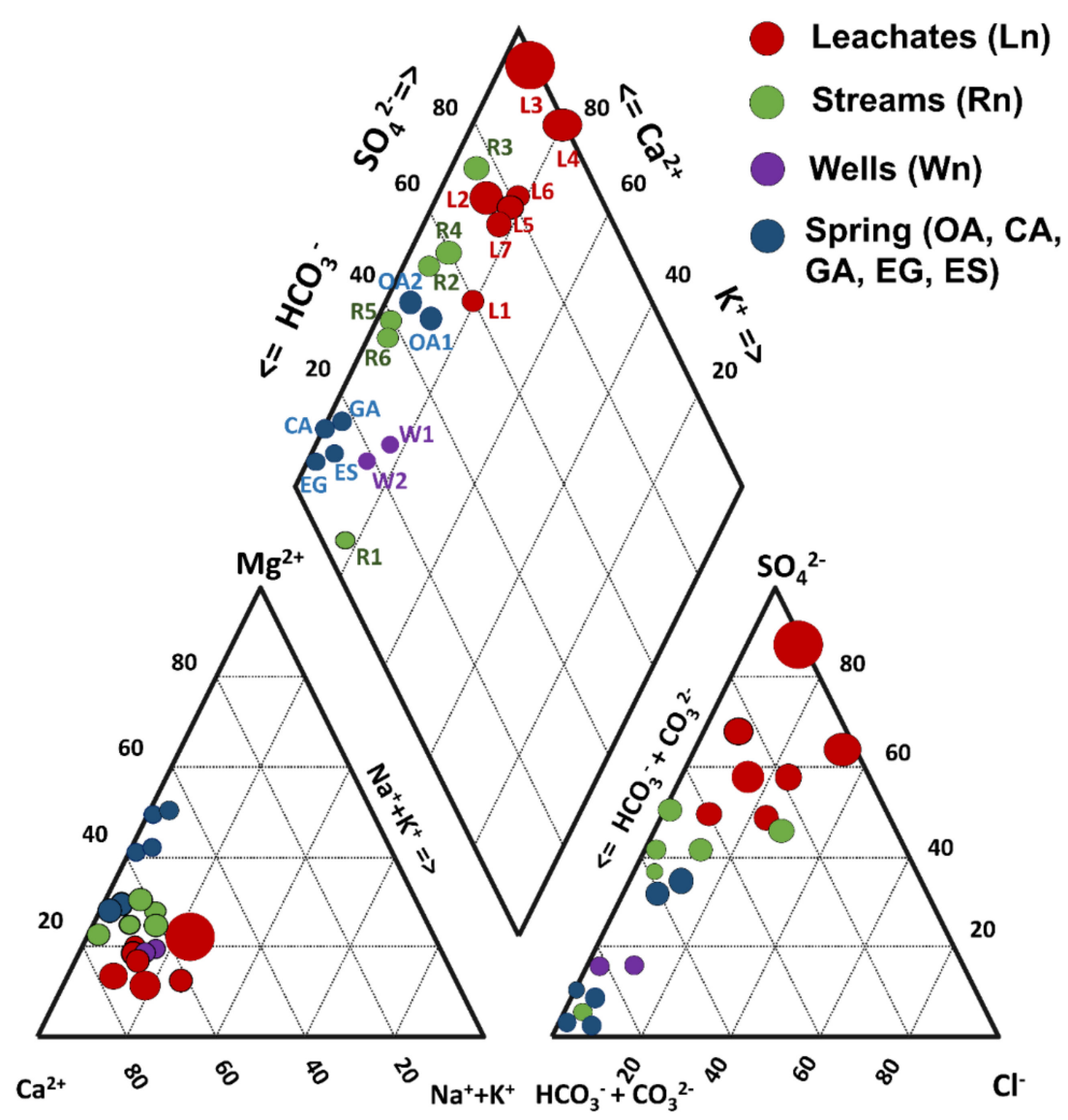

Figure 2. Piper diagrams for the different types of water present in the study area. The size of the marker increases as the EC concentration in the sample increases.

\section{Results and Discussion}

\subsection{As, $\mathrm{Hg}$, and $\mathrm{Tl}$ : The Main Contaminants Identified in the Analyzed Water Bodies}

The As, $\mathrm{Hg}$, and $\mathrm{Tl}$ background values in surface water were established by considering two reference areas. The first reference area (R1) is located close to El Alamo town, and the background values for the Chiquito Stream for As, $\mathrm{Hg}$, and $\mathrm{Tl}$ were 24.7, 33, and $21.7 \mu \mathrm{g} / \mathrm{L}$, respectively. In this reference area, rainwater contacts igneous rocks (ToRP-DaP) in the Zimapan Basin, which could justify these values. The second reference area is close to the Palomas community (Figure 1e), located on the El Abra Formation. In this reference area, the water quality of four springs was characterized, and the As, $\mathrm{Hg}$, and $\mathrm{Tl}$ concentrations exceeded the guidelines for drinking water, except for As in the El Sarro spring (see Table 2). 
Table 2. Physicochemical parameters and chemical concentrations of cations, anions, and trace elements in different types of aqueous samples collected in the study area.

\begin{tabular}{|c|c|c|c|c|c|c|c|c|c|c|c|c|c|c|c|c|c|c|c|c|c|c|c|c|}
\hline \multirow{3}{*}{ Variable } & \multirow{3}{*}{ Units } & \multicolumn{21}{|c|}{ Aqueous Samples } & \multirow[b]{3}{*}{ MDL } & \multirow[b]{3}{*}{ GV } \\
\hline & & \multicolumn{7}{|c|}{ Leachates } & \multicolumn{6}{|c|}{ Streams } & \multicolumn{2}{|c|}{ Wells } & \multicolumn{6}{|c|}{ Springs } & & \\
\hline & & L1 & L2 & L3 & L4 & L5 & L6 & L7 & R1 & $\mathbf{R 2}$ & R3 & R4 & R5 & R6 & W1 & W2 & OA1 & OA2 & GA & CA & EG & ES & & \\
\hline $\mathrm{T}$ & $\left({ }^{\circ} \mathrm{C}\right)$ & 31.2 & 28.6 & 19.9 & 21.3 & 44.9 & 21.5 & 26.4 & 27.2 & 27 & 31.5 & 32.3 & 28.6 & 27.9 & 24.9 & 24.7 & 27.9 & 27.2 & 24.5 & 20.9 & 17.9 & 17.7 & - & - \\
\hline $\mathrm{pH}$ & - & 6.6 & 6.1 & 1.8 & 2.6 & 5.9 & 6.7 & 6.9 & 6.2 & 6.3 & 7.2 & 6.7 & 7.6 & 7 & 6.5 & 6.6 & 6 & 6.2 & 7.1 & 6.8 & 6.9 & 6.9 & - & 6.5 to 8.5 [36] \\
\hline $\mathrm{E}_{\mathrm{H}}$ & $\mathrm{mV}$ & 355 & 382 & 606 & 380 & 416 & 239 & 355 & 406 & 402 & 193 & 377 & 215 & 397 & 343 & 396 & 10 & 359 & 379 & 349 & 362 & 374 & - & - \\
\hline DO & $\mathrm{mg} / \mathrm{L}$ & 10.7 & 4.3 & 3.5 & 6.4 & 0.5 & 3.1 & 6.3 & 4 & 2.8 & 4.1 & 6.4 & 2.3 & 4 & 5.1 & 3.2 & 3.2 & 4.2 & 5.2 & 4.2 & 4.8 & 6 & - & - \\
\hline $\mathrm{EC}$ & $\mu \mathrm{S} / \mathrm{cm}$ & 697 & 1,234 & 8,480 & 2,868 & 1,954 & 691 & 1,102 & 810 & 829 & 1,016 & 1,008 & 970 & 840 & 436 & 466 & 967 & 825 & 600 & 668 & 466 & 456 & - & - \\
\hline $\mathrm{Ca}$ & \multirow{9}{*}{$\mathrm{mg} / \mathrm{L}$} & 73.8 & 169.6 & 314.4 & 69.2 & 205.6 & 86.3 & 157.6 & 27.4 & 110.5 & 53.3 & 111.5 & 113.5 & 88.5 & 63.2 & 67.1 & 113 & 112 & 30.4 & 76.4 & 73.6 & 72.8 & 0.03 & - \\
\hline $\mathrm{Na}$ & & 22.6 & 29.6 & 31 & 21.8 & 42.3 & 20.1 & 29.6 & 6.6 & 6.8 & 4.5 & 8.5 & 11 & 7.1 & 8.2 & 8.3 & 10.6 & 7.1 & 0.4 & 0.9 & $<0.02$ & $<0.02$ & 0.02 & $200[36]$ \\
\hline $\mathrm{K}$ & & 5.1 & 6.4 & 2.6 & 6.8 & 22.2 & 7.2 & 5.3 & 1.7 & 2 & 1.5 & 7.1 & 2.7 & 4.6 & 12.3 & 3.3 & 2.5 & 3.1 & 1 & 0.9 & 1.8 & 1.3 & 0.12 & - \\
\hline $\mathrm{Cl}^{-}$ & & 21.6 & 80.7 & 92.2 & 75 & 30.5 & 68.1 & 116 & $<0.2$ & $<0.2$ & 50.5 & $<0.2$ & 55.6 & $<0.2$ & 20.7 & $<0.2$ & 14 & $<0.2$ & 19.4 & 18.7 & $<0.2$ & $<0.2$ & 0.2 & $250[36]$ \\
\hline $\mathrm{NO}_{3}^{-}$ & & $<10$ & $<10$ & 98.2 & 53.1 & 11.4 & 10.1 & 31 & 75 & $<10$ & 13 & $<10$ & $<10$ & $<10$ & $<10$ & 18.7 & 17.6 & $<10$ & 42 & $<10$ & $<10$ & $<10$ & 10 & $\begin{array}{c}50[35] \\
44.2[36]\end{array}$ \\
\hline $\mathrm{HCO}_{3}{ }^{-}$ & & 126.4 & 206.4 & $<10$ & $<10$ & 172.9 & 57.6 & 215.8 & 110.2 & 248.4 & 61.4 & 215.7 & 229.2 & 270.5 & 233.6 & 282.2 & 265.4 & 263.7 & 206.4 & 250.1 & 350.5 & 274.2 & 10 & $\begin{array}{c}- \\
-\end{array}$ \\
\hline $\mathrm{CO}_{3}^{2-}$ & & 15.5 & 18.1 & $<10$ & $<10$ & 18.1 & 22.8 & 12.9 & 12.9 & 20.6 & 10.7 & 15.5 & 12.1 & 12.9 & 10.3 & 7.7 & 15 & 18.1 & 5.2 & 2.6 & 10.3 & 15.5 & 10 & - \\
\hline $\mathrm{SO}_{4}^{2-}$ & & 140 & 415 & 686 & 150 & 436 & 287 & 327 & 4 & 139.9 & 118.4 & 310.6 & 180.5 & 175.8 & 37.4 & 41.3 & 206.7 & 164.1 & 17.4 & 7.5 & 14.6 & 20 & 0.2 & $400[36]$ \\
\hline $\mathrm{Si}^{\mathrm{Tot}}$ & & 18.9 & 16.7 & 29.5 & 8.4 & 18.9 & 6.9 & 15.3 & 23.3 & 32.4 & 3.7 & 20.3 & 8.4 & 17 & 20.5 & 21.2 & 8.5 & 16.2 & 9.6 & 8.1 & 9.1 & 7.6 & 0.02 & - \\
\hline As & \multirow{10}{*}{$\mu \mathrm{g} / \mathrm{L}$} & 164 & 373 & 69.3 & 34.4 & 93.6 & 47 & 89 & 24.7 & 45 & 17.5 & 14.7 & 44.8 & 47.2 & 26.9 & 23.2 & 121 & 81.5 & 28.2 & 43.2 & 9.1 & 5 & 3 & $10[36] 25[36]$ \\
\hline $\mathrm{Tl}$ & & 14.5 & $<10.3$ & 918 & 16.5 & 21.1 & 73 & 22.3 & 21.7 & 22.7 & 18.7 & 30.4 & 26.8 & 16.7 & 12.4 & 19.3 & 49.1 & 23.6 & 15 & 21.6 & 17.1 & 18.7 & 10 & 13 [37] \\
\hline $\mathrm{Pb}$ & & $<5$ & $<5$ & 27.4 & 6.9 & $<5$ & 6.9 & 9.5 & $<5$ & $<5$ & 5.7 & $<5$ & 27.5 & $<5$ & 8.3 & 5.2 & 55.2 & $<5$ & $<5$ & $<5$ & $<5$ & $<5$ & 5 & $10[35,36]$ \\
\hline $\mathrm{Fe}$ & & $<6.2$ & 6.2 & $\begin{array}{c}1 \\
214\end{array}$ & 100 & 11 & 33.6 & $<6.2$ & 33.7 & 43 & 10.4 & $<6.2$ & 16.4 & $<6.2$ & $<6.2$ & 8.2 & $<6.2$ & 17.9 & $<6.2$ & 7.65 & $<6.2$ & $<6.2$ & 6.2 & $300[36]$ \\
\hline $\mathrm{Cu}$ & & $<11.9$ & $<11.9$ & $\begin{array}{c}2 \\
559\end{array}$ & 25.1 & 35.5 & 16.2 & $<11.9$ & $<11.9$ & $<11.9$ & $<11.9$ & $<11.9$ & $<11.9$ & $<11.9$ & 6.1 & 6.6 & 11.9 & $<11.9$ & $<11.9$ & $<11.9$ & $<11.9$ & $<11.9$ & 11.9 & 2000 [35] \\
\hline $\mathrm{Zn}$ & & $<5$ & 22.4 & 12,924 & 52 & 314 & 11.5 & $<5$ & 5.3 & $<5$ & 14.7 & $<5$ & 46.4 & $<5$ & $<5$ & 8.5 & 12.2 & $<5$ & 8.4 & $<5$ & $<5$ & $<5$ & 5 & 3000 [35]; 5000 [36] \\
\hline $\mathrm{Sr}$ & & 579 & $\begin{array}{c}1 \\
054\end{array}$ & 436 & $\begin{array}{c}1 \\
107\end{array}$ & $\begin{array}{c}2, \\
042\end{array}$ & 380 & $\begin{array}{r}1 \\
105\end{array}$ & 191 & 924 & 602 & $\begin{array}{c}1 \\
220\end{array}$ & 656 & 949 & 294 & 312 & $\begin{array}{c}1 \\
211\end{array}$ & 958 & 67 & 65 & 95 & 62 & 3.4 & 4000 [35] \\
\hline $\mathrm{Al}$ & & 5.6 & 11.4 & $\begin{array}{r}16 \\
356\end{array}$ & 303 & 23.6 & 24.7 & $<5$ & 10.7 & 12.8 & 7.8 & $<5$ & 36.1 & $<5$ & $<5$ & $<5$ & 14.8 & 5.2 & 13 & 26.3 & $<5$ & $<5$ & 5 & $200[36]$ \\
\hline $\mathrm{Sb}$ & & 15.6 & 16.2 & 34.2 & 64 & 21.2 & 69.2 & 20.1 & 17.7 & 16.4 & 28.4 & 15.6 & 57.3 & 14.6 & 13 & 15.8 & 43 & 13.4 & 11.8 & 15.4 & 12.2 & 11.4 & 9.7 & 20 [35] \\
\hline Se & & $<7.3$ & $<7.3$ & 14 & 15.4 & 10.2 & 14.6 & 11.3 & 11 & 8.32 & 14 & $<7.3$ & 15.3 & $<7.3$ & $<7.3$ & $<7.3$ & 14.2 & $<7.3$ & 16.5 & $<7.3$ & $<7.3$ & 21.6 & 7.3 & 40 [35] \\
\hline $\mathrm{CI}$ & $\%$ & 12.4 & -18 & 95.6 & 30.7 & 27.5 & -42 & -23.8 & -33.3 & 13 & -22.6 & -12.1 & -7.3 & -17.3 & -12.8 & -23.8 & -11.6 & 4.1 & -7.1 & 37.5 & 15.4 & 16 & - & - \\
\hline
\end{tabular}

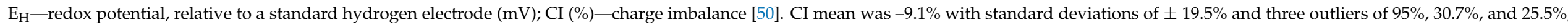

MDL—-method detection limit; GV—guideline values for drinking water, established by the World Health Organization [35], the Mexican normative [36], or the Environmental protection agency [37]. 
Table 2 shows the results of the physicochemical analyses, the concentrations of major and trace elements in the water samples, the method detection limit (MDL) for each parameter, and the guideline values (GVs) for drinking water [35-37]. A global chemical balance of aqueous samples allowed the estimation of a mean CI value of $-9.1 \%$ with standard deviations of $\pm 19.5 \%$ and three outliers of $95.6 \%, 30.7 \%$, and $27.5 \%$ for samples corresponding to the L3, L4, and L5 leachates, respectively. In the Piper diagram, three water families could be differentiated (Figure 2). The water from two community wells (W1 and W2), the Chiquito Stream (R1), and springs located in the Palomas reference area (Table 2) were mainly bicarbonate-calcium type with a low sulfate content (4 to $20 \mathrm{mg} / \mathrm{L}$ ). The river water samples (R2 to R6) were classified as a mixed type (sulfate-bicarbonatecalcium), with intermediate sulfate concentrations (118-310 mg/L). Additionally, a Piper diagram indicated that the leachates from mine waste presented high values of EC and $\mathrm{SO}_{4}{ }^{2-}$ and low or null concentrations of bicarbonate and carbonate (Figure 2). In addition, Pearson's correlation for the leachates indicated that there was a strong positive correlation between $\mathrm{Ca}$ and $\mathrm{SO}_{4}{ }^{2-}\left(R^{2}=0.87\right)$. This suggested that gypsum could be the phase that controls the presence of $\mathrm{SO}_{4}{ }^{2-}$ ions in this type of sample, associated with the calculated SI ( -0.6 to -2.1 , cf. Section 4.5). High correlations among $\mathrm{Al}, \mathrm{Cu}, \mathrm{Fe}, \mathrm{Tl}$, and $\mathrm{Zn}$ concentrations $\left(0.92<R^{2}<0.99\right)$ evidenced the leaching of mineral sulfides contained in the ore of the abandoned La Aurora mine, which was rich in Cu-Fe-Zn-S [43-45]. This was also supported by the correlations observed between some metal ions $(\mathrm{Cu}, \mathrm{Fe}$, and $\mathrm{Zn})$ and $\mathrm{SO}_{4}{ }^{2-}$ ions $\left(R^{2}=0.54,0.46\right.$, and 0.55, respectively). Blowes et al. [7] established that $\mathrm{IOH}-\mathrm{SO}_{4}{ }^{2-}$ in AMWDs can release acidity when metallic ions adsorbed in these secondary minerals dissolve during runoff and then undergo hydrolysis. According to this, two hypothetical release mechanisms could be considered: (1) acid dissolution of polymetallic sulfides in AMWDs and (2) dissolution of PTE-bearing SMPs (including jarosites and $\mathrm{IOH}_{-} \mathrm{SO}_{4}{ }^{2-}$, amorphous or crystalline, or both) that migrated from flowing water to other water bodies, thus changing their SI condition [55].

\subsection{PCA Values: A Strategy to Establish the Quality of Water Bodies}

Principal component analysis showed a classification of variables and types of samples based on the projection of variable correlation plots that allowed the identification of four clusters (Figure 3a,b). Five principal components explained $82.2 \%$ of the total variance in the data for the analyzed water samples (Table S2). The PC1 and PC2 planes explained $55.4 \%$ of the total variance. The PC1 component was mainly composed of eigenvectors with positive values that ranged from 0.228 to 0.312 , corresponding to the $\mathrm{EC}, \mathrm{Cu}, \mathrm{Al}, \mathrm{Fe}$, $\mathrm{Tl}, \mathrm{Ca}$, and $\mathrm{SO}_{4}{ }^{2-}$ variables. For the PC2 component, the eigenvectors with positive values ranging from 0.237 to 0.415 correspond to $\mathrm{Sr}, \mathrm{K}, \mathrm{Na}, \mathrm{As}, \mathrm{CO}_{3}{ }^{2-}, \mathrm{SO}_{4}{ }^{2-}$, and Ca variables. The main variables of PC1 suggested a chemical signature associated with weathering of polymetallic sulfide mineral phases that were originally present in the AMWD (Table S2). In addition, the main variables of PC2 suggest that the physicochemical dissolution of As-bearing secondary phases is constituted by $\mathrm{IOH}_{-} \mathrm{SO}_{4}{ }^{2-}$ (Table S2; Figure 3a). The above could explain why the presence of As in the El Ojo de Agua spring is due to the migration of fine particles of SMPs throughout the water flow until reaching the spring. The release of As in surface water derives from chemical instability associated with physicochemical conditions (Figure 4).

The eigenvectors of As, $\mathrm{K}$, and $\mathrm{Sr}$ were projected in the same direction as the eigenvectors of $\mathrm{SO}_{4}{ }^{2-}, \mathrm{Na}$, and $\mathrm{Ca}$. These ions were associated with celestite, gypsum, $\mathrm{K}$-jarosite, or Na-jarosite as the main SMPs carrying the elements identified in the area (Figure 3a, quadrant I). This finding was supported by both chemical and XRD analyses of stream sediments, which are described in Section 4.5 The orientation and magnitude of eigenvectors of $\mathrm{pH}$ and $\mathrm{HCO}_{3}{ }^{-}$indicated natural water or samples from rivers not impacted by AMD (or both) (Figure 3a). 

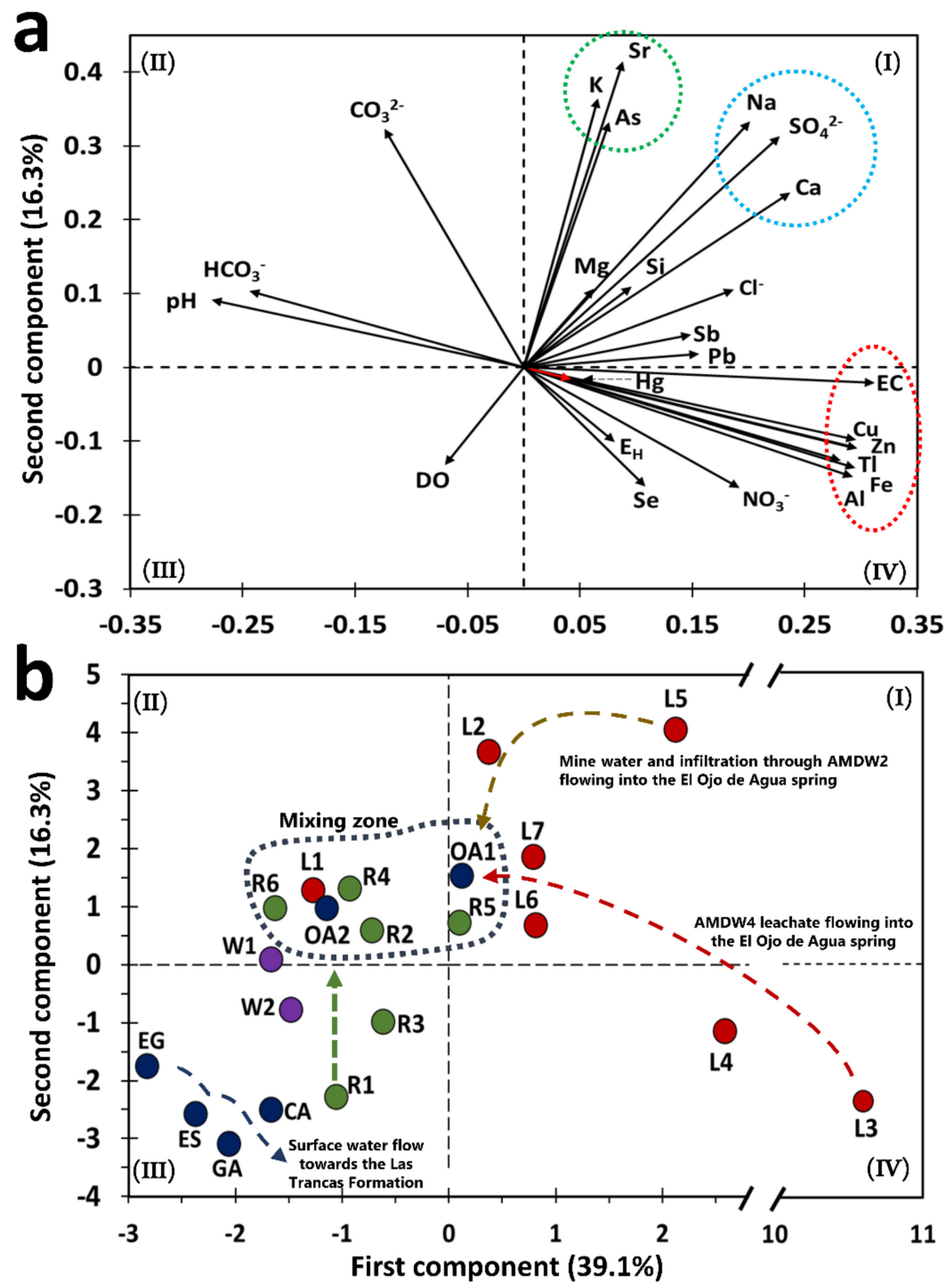

Figure 3. Principal component analysis for the water samples collected in the study area. (a) Eigenvector of the variables considered in the PCA. (b) Projection of the leachate samples (red circle), wells (purple circle), rivers (green circle), and springs (blue circle).

In the case of water samples, the PC1 vs. PC2 plane showed a group consisting of drinking water supply sources (springs in the Palomas reference area and wells of the La Laja community) and the Chiquito Stream (R1), which corresponds to a water sample not impacted by leachates from AMWDs (Figure 3b). These samples were characterized by neutral $\mathrm{pH}$ and high $\mathrm{HCO}_{3}{ }^{-}$concentrations, which could be related to the limestone dissolution reaction from the El Abra Formation, flowing toward the Las Trancas Formation.

The water samples of the springs located in the Palomas reference area (GA, CA, EG, and $\mathrm{ES}$ ) presented a range of $\mathrm{As}, \mathrm{Hg}$, and $\mathrm{Tl}$ concentrations between 5 and $43.2,<10$ to 32.6, and 15 to $21.6 \mu \mathrm{g} / \mathrm{L}$, respectively (Table 2). These concentration values were associated with the water-rock interactions between rainwater and volcanic rocks $[55,56]$. The highest measured As, $\mathrm{Hg}$, and $\mathrm{Tl}$ concentrations were 43.2, 32.6, and $21.6 \mu \mathrm{g} / \mathrm{L}$, respectively, in the CA spring (located at 1162 m.a.s.l.).

Although the PCA values strategy permitted classifying all water samples as a preliminary approach for the water quality index, it was necessary to deepen the analysis to find 
the causes that give rise to possible contamination. At this point, only four water samples were classified as uncontaminated (W1, W2, EG, and ES), three samples were classified as slightly-moderately contaminated (R1,CA, and GA), and the rest of the samples presented a grade of strongly-extremely contaminated, including the El Ojo de Agua spring (Table S3).

Figure $3 b$ shows that the W1 and W2 samples were located outside of the surface water mixing zone. The inhabitants of the La Laja community use these wells as drinking water sources, despite this water containing $25 \pm 2 \mu \mathrm{g} / \mathrm{L} \mathrm{As,} 18 \pm 10 \mu \mathrm{g} / \mathrm{L} \mathrm{Hg}$, and $16 \pm 5 \mu \mathrm{g} / \mathrm{L} \mathrm{Tl}$. These values are above the guidelines for drinking water quality (Table 2); hence, it is necessary to determine the sources of these elements. Sulfate concentrations in wells were five times lower than those observed in the Santa María River or the El Ojo de Agua spring. This confirmed that W1 and W2 were not impacted by $\mathrm{SO}_{4}{ }^{2-}$ and could instead be associated with recent infiltration waters. The $\mathrm{SO}_{4}{ }^{2-}, \mathrm{As}, \mathrm{Hg}$, and $\mathrm{Tl}$ concentrations resembled the values determined in the reference zones (Table 2). The water samples observed in the mixing zone were mainly composed of river water samples (R2, R4, R5, and R6), one sample collected from the irrigation channel that surrounds AMWD1 (L1), and two samples from the El Ojo de Agua spring (OA1 and OA2).

Figure $3 b$ shows that the W1 and W2 samples were located outside of the surface water mixing zone. The inhabitants of the La Laja community use these wells as drinking water sources, despite this water containing $25 \pm 2 \mu \mathrm{g} / \mathrm{L} \mathrm{As,} 18 \pm 10 \mu \mathrm{g} / \mathrm{L} \mathrm{Hg}$, and $16 \pm 5 \mu \mathrm{g} / \mathrm{L} \mathrm{Tl}$. These values are above the guidelines for drinking water quality (Table 2); hence, it is necessary to determine the sources of these elements. Sulfate concentrations in wells were five times lower than those observed in the Santa María River or the El Ojo de Agua spring. This confirmed that W1 and W2 were not impacted by $\mathrm{SO}_{4}{ }^{2-}$ and could instead be associated with recent infiltration waters. The $\mathrm{SO}_{4}{ }^{2-}, \mathrm{As}, \mathrm{Hg}$, and $\mathrm{Tl}$ concentrations resembled the values determined in the reference zones (Table 2). The water samples observed in the mixing zone were mainly composed of river water samples (R2, R4, R5, and R6), one sample collected from the irrigation channel that surrounds AMWD1 (L1), and two samples from the El Ojo de Agua spring (OA1 and OA2).

The results from L5 represent the water quality in the flooded area of the La Aurora mine (Figure 3b) from samples collected from a household water tap (L5) connected to this area. This water sample was located near AMWD2, and it was used for sanitary and cleaning services. The measured $\mathrm{As}, \mathrm{Hg}, \mathrm{Tl}$, and $\mathrm{SO}_{4}{ }^{2-}$ concentrations were 94, 37.4, $21.1 \mu \mathrm{g} / \mathrm{L}$, and $436 \mathrm{mg} / \mathrm{L}$, respectively (Table 2). These elements could be considered geochemical markers of metal sulfide oxidation taking place underground [7]. In fact, L3, L4, and L5 represent water samples were severely impacted by mine waste and were classified as extremely contaminated by the PCA values (Table S3).

The L3 and L4 samples were collected from the Xichú Stream just below the AMWDs, and both samples presented high concentrations of $\mathrm{SO}_{4}{ }^{2-}, \mathrm{Al}, \mathrm{Cu}, \mathrm{Fe}$, and $\mathrm{Zn}$, which are characteristic of sites impacted by mine waste drainages [57]. The leachate samples were also characterized by high As contents as a result of water-waste interactions during infiltration through the porous spaces in tailings (L2 to L7 samples). The As, $\mathrm{Hg}$, and T1 concentrations in the leachate samples ranged from 34 to $373,8.6$ to 39.7 , and 10 to $918 \mu \mathrm{g} / \mathrm{L}$, respectively. It is important to highlight that the samples with the highest concentrations of As, $\mathrm{Hg}$, and $\mathrm{Tl}$ were $\mathrm{L} 2, \mathrm{~L} 4$, and $\mathrm{L} 3$, respectively. Because of the $\mathrm{SO}_{4}{ }^{2-}$ concentrations, the L2, L4, L6, and L7 samples were considered surface waters that had been impacted by leachates from AMWDs. Figure $3 b$ shows the confluence of these samples toward a mixing zone and the flow of leachates to the same zone. The mixing zone is constituted mainly by the Santa Maria River and El Ojo de Agua spring water samples. In the PCA diagram, L1 is a sample that surrounds a mining deposit and contains a high concentration of As $(164 \mu \mathrm{g} / \mathrm{L})$ and a higher concentration of DO $(10.7 \mathrm{mg} / \mathrm{L})$. This can be explained by the high photosynthetic activity observed in the field, derived from the presence of algae that promote high concentrations of DO [58,59], and low concentrations of the inorganic markers associated with mine drainage $\left(\mathrm{SO}_{4}{ }^{2-}, \mathrm{Fe}, \mathrm{Cu}\right.$, and $\left.\mathrm{Zn}\right)$. 


\subsection{El Ojo de Agua Spring: As a Potential Drinking Water Supply, Is It Impacted by Natural or} Anthropogenic Events?

The El Ojo de Agua spring feeds the flow of the La Laja stream with a perennial flow rate of almost $1000 \mathrm{~L} / \mathrm{s}$. The samples collected $380 \mathrm{~m}$ upstream from the source of the Ojo de Agua spring (R2) and $200 \mathrm{~m}$ upstream of the confluence between La Laja Stream and the Santa María River (R6, Figure 1f) showed decreases in As, $\mathrm{Hg}$, and $\mathrm{Tl}$ concentrations (Table 2). The confluence between the La Laja Stream and the Santa María River leads to equilibrium $\mathrm{pH}$ and $\mathrm{E}_{\mathrm{H}}$ values of 7 and $397 \mathrm{mV}$, respectively (Figure 4, Table 2). These values were explained by neutralization reactions occurring because of dissolution of limestone rock and adequate aeration (see reactions in Table S4).

In the El Ojo de Agua spring, a rapid response to the variation in the $\mathrm{E}_{\mathrm{H}}$ indicated an alteration of its water quality [60]. Some parameters, such as trace element concentrations of $\mathrm{As}, \mathrm{Pb}, \mathrm{Zn}, \mathrm{Sr}$, and $\mathrm{Tl}$, also showed a response to a recent rainfall event, decreasing in concentration due to a dilution effect (Table 2). However, on a dry day, the inorganic markers associated with beudantite dissolution $\left(\mathrm{Pb}, \mathrm{As}\right.$, and $\left.\mathrm{SO}_{4}{ }^{2-}\right)$ increased due to low $\mathrm{E}_{\mathrm{H}}(10 \mathrm{mV})$ (see reactions in Table S4). Figure 4 shows different SMPs, such as scorodite, $\mathrm{IOH}$, and $\mathrm{IOH}-\mathrm{SO}_{4}{ }^{2-}$, their stability zones, and As-soluble species. The increase in Fe concentration (Table 2) was likely related to the entrainment of colloids or fine particles rich in SMP on rainy days $[7,61]$.

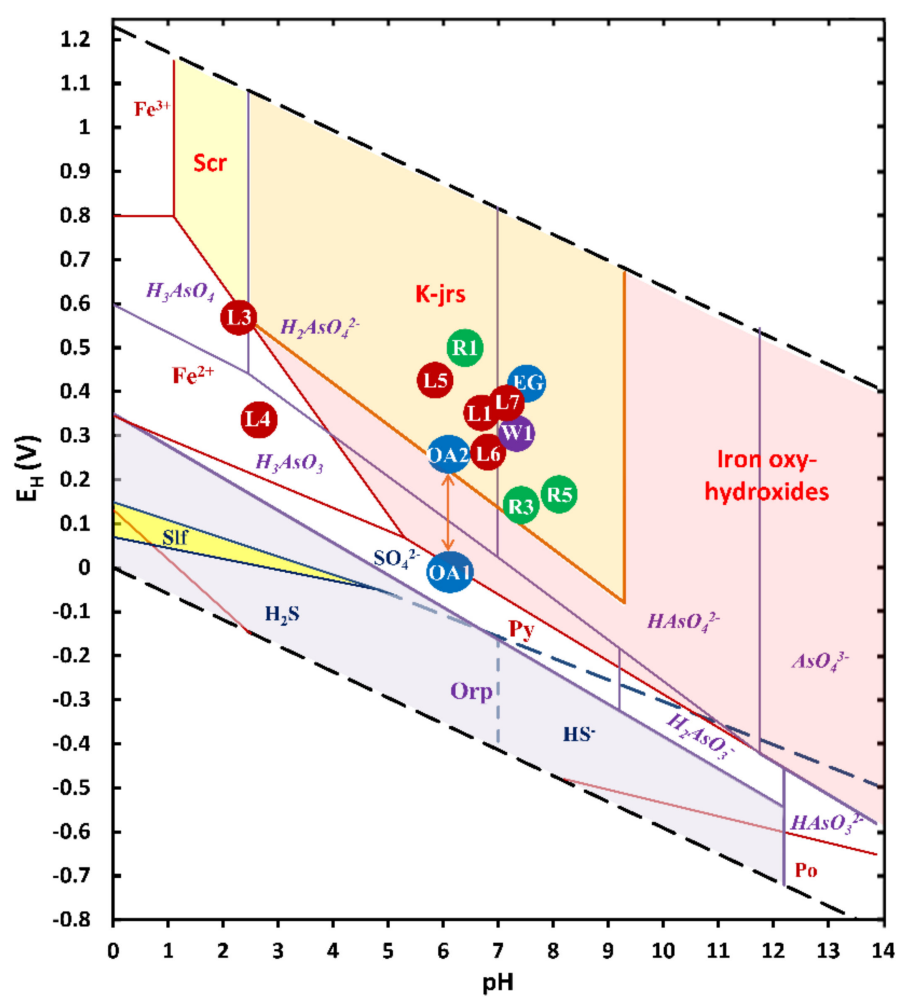

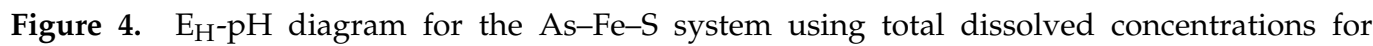
$[\mathrm{As}]=5 \mathrm{mM},[\mathrm{Fe}]=5 \mathrm{mM}$, and $\left[\mathrm{SO}_{4}{ }^{2-}\right]=0.71 \mathrm{mM}$ (Constructed using MEDUSA code [62].

At this point, it is possible to postulate a conceptual model of water and finer PTEbearing particle movement in the study area (Figure 5). Thus, the presence of As could be associated with the contribution of solid SMPs that carry this element from the leachate of the AMWD. It is also suggested that As could have migrated through the surface stream sediments or vadose zone until reaching this water body, as was observed in the mining district of Cerro de San Pedro in San Luis Potosí [61]. The presence of geological fractures filled with iron oxides and carbonates has been documented in a transect transverse to the Xichú Stream channel, which crosses the area of mine waste dumps [32]. These interstitial iron oxides could be associated with secondary mineral products of the pyrite oxidation 
present in the AMWDs and the natural oxidation of the sulfides in rocks. The iron oxides that migrate from waste dumps as fine materials are potential As-bearing SMPs. In these phases, As can be occluded, coprecipitated, or adsorbed. Arsenic that is adsorbed or coprecipitated on $\mathrm{IOH}$ particles (amorphous or crystalline, or both), which fill the fractures in the area, can be released by ion exchange reactions or by reductive dissolution when the particles migrate to sites with anoxic conditions [55].

Additionally, the water quality response from the El Ojo de Agua spring could be associated with the effect of geological water-rock interactions between the Zimapan Basin, the Valle-San Luis Potosí Platform, and the Las Trancas Formation. This geological condition has led to an interesting finding that explains the presence of $\mathrm{Hg}$ in the springs of the Palomas reference zone and the El Ojo de Agua spring. The Hg concentrations can be attributed to rainwater-mineralized igneous rock interactions (ToRP-DaP). In fact, near this zone, under similar geological conditions, cinnabar ores occur, and low quantities of $\mathrm{Hg}$ are present in the volcanic rocks [63]. It is important to notice that there are not historical records or physical evidence of amalgamation processes carried out in this site, although there is evidence of an ancient mercury mine at $70 \mathrm{Km}$ SE of the site. For instance, Martínez-Trinidad et al. [64] reported concentrations of 0.6 to $687 \mathrm{mg} / \mathrm{kg} \mathrm{Hg}$ in sediments near San Joaquin Querétaro.

\subsection{Isotopic Analysis of $\delta^{34} S_{\text {sulfate }}, \delta^{18} \mathrm{O}_{\text {sulfate, }}$ and Sulfate Presence in the El Ojo de Agua Spring}

The origin of sulfate in the El Ojo de Agua spring was determined by the isotopic

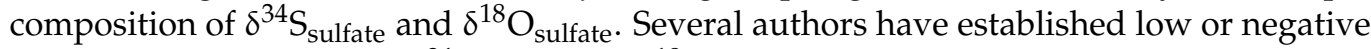
isotopic compositions of $\delta^{34} \mathrm{~S}_{\text {sulfate }}$ and $\delta^{18} \mathrm{O}_{\text {sulfate }}$ associated with sulfide oxidation in mining areas [65-68]. In Figure 6a, samples L1, L3, and L7 are grouped in a cluster with similar $\delta^{34} S_{\text {sulfate }}$ vs. $1 /\left[\mathrm{SO}_{4}{ }^{2-}\right]$ ratios, located in a region characterized by sulfide oxidation, which in this study is labeled the AMD zone. These results supplement a similar study by Brenot et al. [65]. The well water samples (W1 and W2) from the La Laja community had a $\delta^{34} S_{\text {sulfate }}$ vs. $1 /\left[\mathrm{SO}_{4}{ }^{2-}\right]$ ratio closer to the ratio $\left(\delta^{34} \mathrm{~S}_{\text {sulfate }}\right.$ vs. $\left.1 /\left[\mathrm{SO}_{4}{ }^{2-}\right]\right)$ of leachate samples but were also influenced by surface runoff and infiltration of rainwater connected through the multiple geological faults, documented in the Palomas reference zone [38]. The $\delta^{34} \mathrm{~S}_{\text {sulfate }}$ vs $1 /\left[\mathrm{SO}_{4}{ }^{2-}\right]$ ratio, attributed to the GA and CA springs, is mainly associated with rainwater values reported by Brenot et al. [65]. Finally, a third cluster, attributed to the evaporite zone by Brenot et al. [65], was identified and conformed to that of the El Ojo de Agua spring, the Santa María River (R4), and its confluence with the La Laja Stream (R6), which is different from the two previously identified clusters (Figure 6a). Previous results established that the presence of the $\mathrm{SO}_{4}{ }^{2-}$ ions in the El Ojo de Agua spring came from a different source than mining residues in the study area, suggesting that there was no direct connection between the sulfates generated by the mine wastes and sulfate ions found in this spring. The isotopic compositions of $\delta^{18} \mathrm{O}_{\text {sulfate }}$ and $\delta^{34} \mathrm{~S}_{\text {sulfate }}$ are projected in Figure $6 \mathrm{~b}$. Isotopes values of $\delta^{18} \mathrm{O}_{\text {sulfate }}$ could be associated with three different processes of input and output $\mathrm{SO}_{4}{ }^{2-}$ fluxes identified in the study zone, which are associated with the following: (1) mineral sulfide oxidation weathering by atmospheric oxygen (L5 and L7), with a range of values of $\delta^{18} \mathrm{O}_{\text {sulfate }}$ between +1 and +1.8 ; (2) $\mathrm{SO}_{4}{ }^{2-}$-bearing secondary mineral precipitation by oversaturation of $\mathrm{SO}_{4}{ }^{2-}$ via AMWDs weathering, with a range of values of $\delta^{18} \mathrm{O}_{\text {sulfate }}$ between +2.2 and +3.9 ; (3) the dissolution of old Cretaceous evaporites of $\mathrm{SO}_{4}{ }^{2-}$, with a range of values of $\delta^{18} \mathrm{O}_{\text {sulfate }}$ between $\sim+10$ and $+11[68,69]$. These values agree with those reported by Otero et al. [68] and Claypool et al. [69]. 


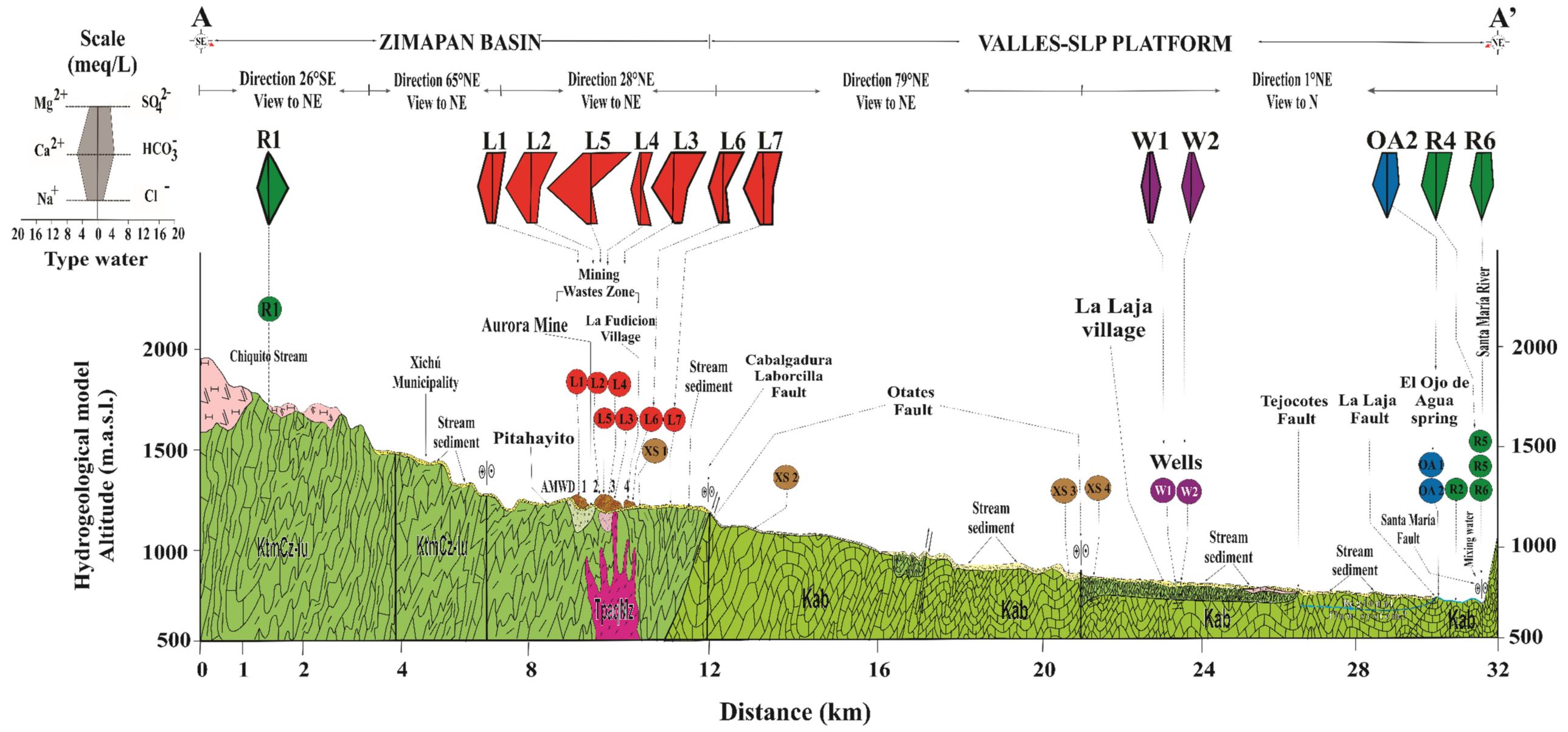

Figure 5. Conceptual model of water and flux of fine PTE-bearing particles in the study area. Leachate samples in red circles are under acid-neutral and oxidant conditions. 


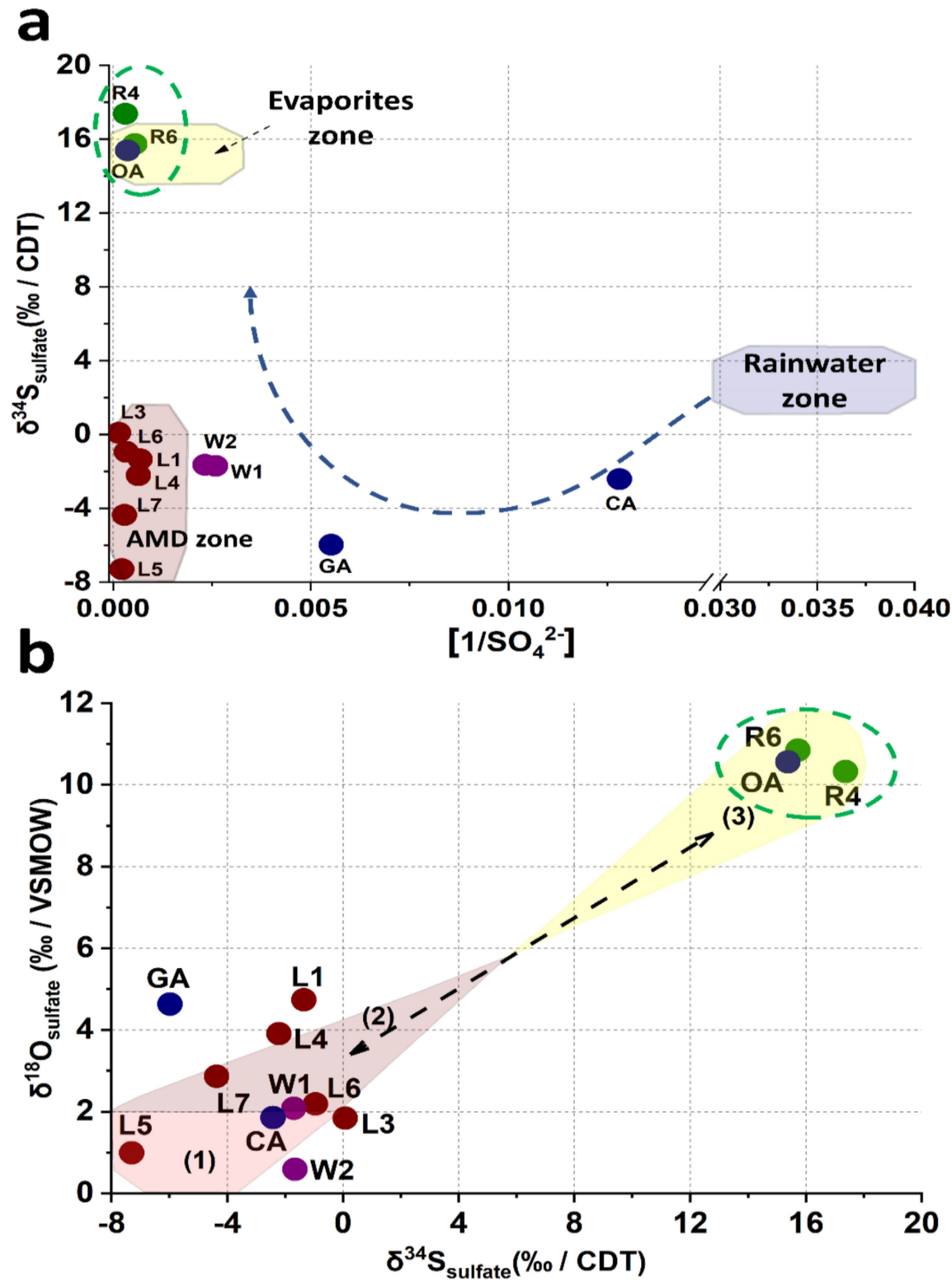

Figure 6. Isotopic analysis. (a) $\delta^{34} \mathrm{~S}_{\text {sulfate }}$ values vs. the $1 /\left[\mathrm{SO}_{4}{ }^{2-}\right]$ ratio showing the rainwater zone and evaporite zones and defining a new zone in this study for water quality associated with AMD produced by sulfide oxidation.(b) Isotope values of $\delta^{18} \mathrm{O}_{\text {sulfate }}$ and $\delta^{34} \mathrm{~S}_{\text {sulfate }}$ associated with each input and output flux of sulfate. The shadow areas represent the identified processes that correspond to (1) mineral sulfide oxidation, (2) precipitation of sulfate secondary minerals by oversaturation, and (3) old Cretaceous evaporite dissolution from the El Abra Formation.

The isotopic signature in the El Ojo de Agua spring is the same as that in the Santa Maria River, and this last isotopic signature agrees well with the $\delta^{18} \mathrm{O}_{\text {sulfate }}$ and $\delta^{34} \mathrm{~S}_{\text {sulfate }}$ isotopic signatures in Cretaceous evaporites for marine evaporite $\mathrm{SO}_{4}{ }^{2-}$ dissolution reported by Claypool et al. [69]. Basáñez-Loyola et al. [70] described that the El Abra Formation was constituted by three depositional environmental events, among which, two were associated with evaporitic lagoons, which is in line with the isotopic results observed in this study. Therefore, it is possible to postulate that the sulfate incorporated into the El Ojo de Agua spring originated from the rock-water interactions of the geological formation, within which it was structurally confined via the evaporitic $\mathrm{SO}_{4}{ }^{2-}$ content in the El Abra Formation. Otherwise, the origin of $\mathrm{SO}_{4}{ }^{2-}$ did not correlate with the origin of As in the El Ojo de Agua spring because the increased contribution of sulfates could be 
related to an underground geological structure connecting the Santa María River and the El Ojo de Agua spring (Figure 5) via the Santa María and La Laja lateral faults (Figure 1b). Likewise, the concentrations of $\mathrm{SO}_{4}{ }^{2-}$ in the samples from the Santa María River and isotopic compositions of $\delta^{34} \mathrm{~S}_{\text {sulfate }}$ and $\delta^{18} \mathrm{O}_{\text {sulfate }}$ remained relatively constant, as was observed by Brenot et al. [64] regarding the temporal and spatial variations in water quality in the Moselle River Basin. Thus, while the presence of $\mathrm{SO}_{4}{ }^{2-}$ could be of natural origin, the presence of As could not.

4.5. Arsenic Content in the El Ojo de Agua Spring and its Relationship with the Dragging of Fine Particles via Hydric Erosion

$\mathrm{XRD}, \mathrm{XRF}$, and SEM analyses were paramount in elucidating the origin of As in the El Ojo de Agua spring and its relationship with the contributions of secondary minerals from mine waste dumps (Figures 7 and 8). SMPs identified by XRD analysis were associated with the weathering products of AMWDs from the reactions described in Table S4. In fact, As-bearing SMPs could contain As that was coprecipitated (in gypsum or jarosites), adsorbed (in jarosites or goethite), or even part of the SMP structure (e.g., scorodite, beudantite, or IOH phases-amorphous or crystalline). In this study, the AMWDs were considered the sources of As due to an average concentration of $9300 \pm 7400 \mathrm{mg} / \mathrm{kg}$, which shows a heterogenic distribution and great diversity of primary and $\mathrm{As}-\mathrm{Pb}$-bearing SMPs (Figure 7).

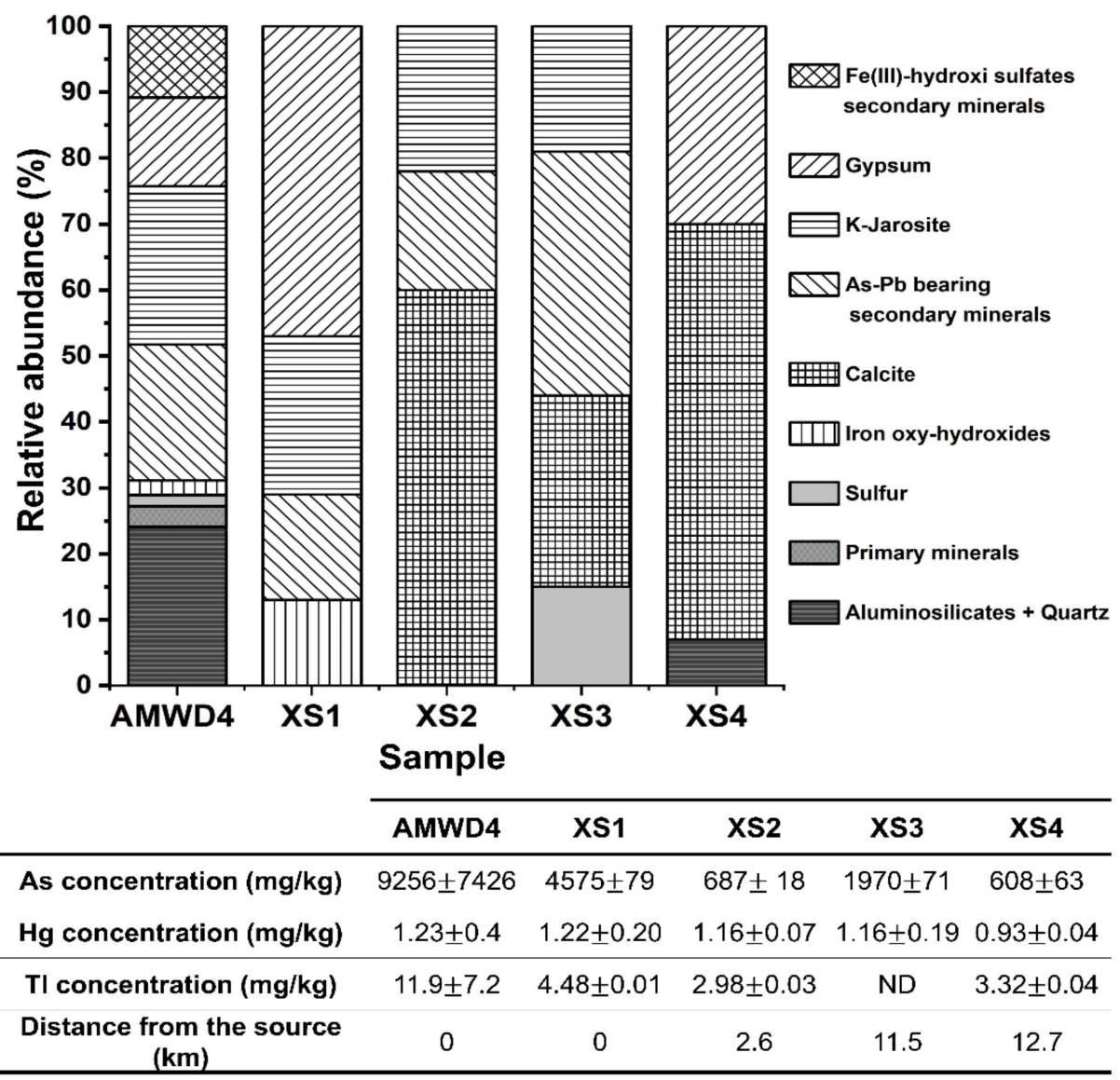

Figure 7. Relative abundance of mineral phases identified by XRD in the wall of AMWD4, stream sediment samples, and the corresponding $\mathrm{As}, \mathrm{Hg}$, and $\mathrm{Tl}$ total concentrations (mg/kg). The As- $\mathrm{Pb}-$ bearing secondary minerals are represented by beudantite, Pb-jarosites, Lautite, Lanarkite, Segnetite, scorodite, and Sarkinite. Fe(III)-hydroxi-sulfate secondary minerals correspond to ferricopiapite and coquimbite. Iron oxides correspond to goethite and lepidocrocite. Primary minerals correspond to pyrite and chalcocite (see Table 3). 

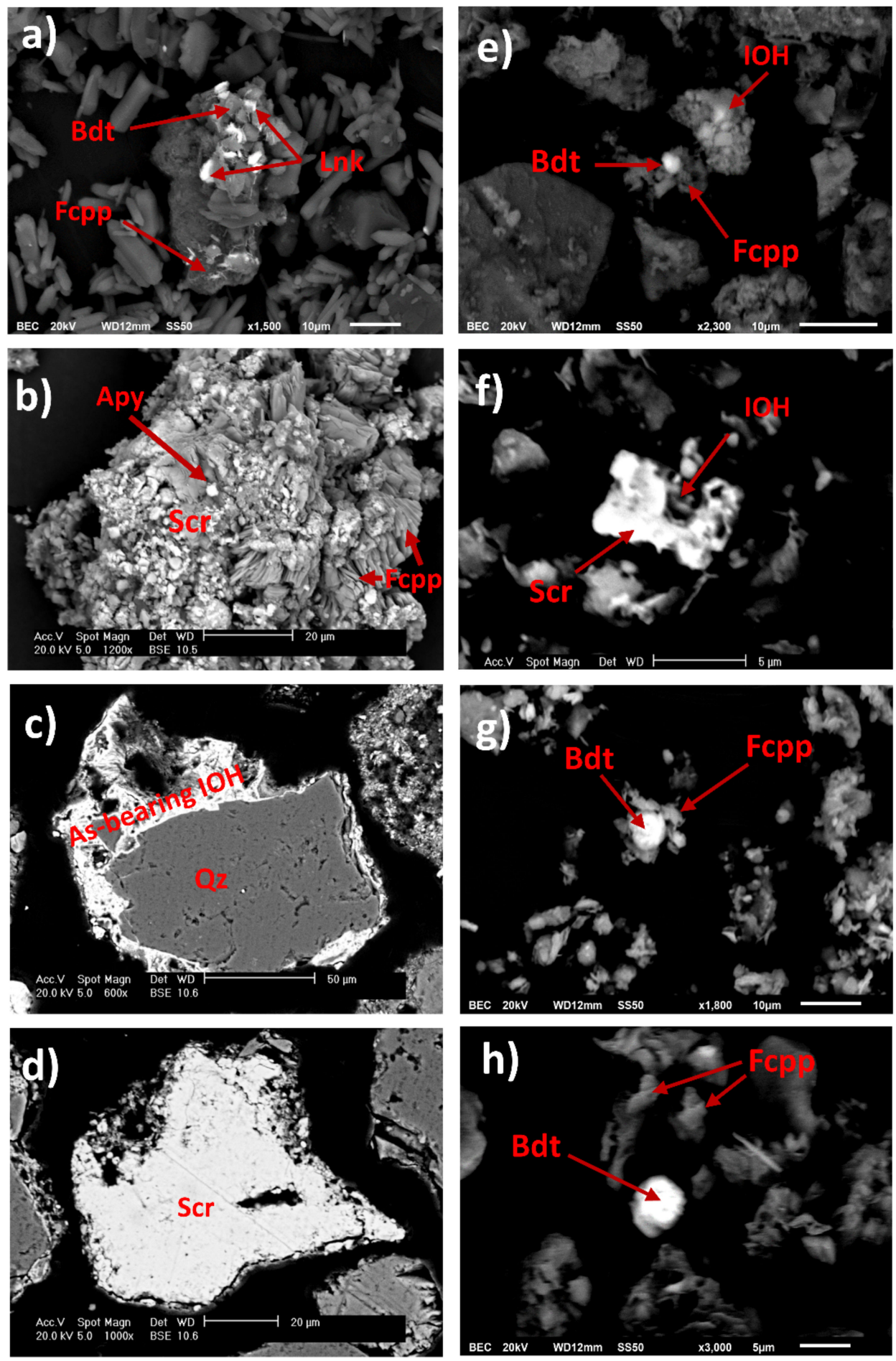

Figure 8. Photomicrographs of particles present on the wall of AMWD4 (a) and (b); stream sediments XS1 (c) and (d), XS2 (e), XS3 (f) and (g), and XS4 (h). SEM-EDS point analysis suggests the presence of arsenopyrite (Apy), beudantite (Bdt), scorodite (Scr), As-bearing IOH, ferricopiapite (Fcpp), and lanarkite (Lnk) (see Table S5).

The SEM observations show that fine particles such as lanarkite and beudantite were disseminated and scattered around ferricopiapite in wall lateral AMWD samples (Figure 8a). In addition, it was even possible to observe Scorodite particles, one of the most representative As-bearing mineral phases in AMWD (Figure 8b,d,f). Scorodite mineral particles were evidenced in the walls of AMWD4, probably due to arsenopyrite oxidation 
and gradual conversion into $\mathrm{Fe}$ arsenate via $\mathrm{AsO}_{4}{ }^{3-}$ into scorodite in $\mathrm{AMD}$ conditions as it has also been observed by Dill et al. [71] (Figures $8 \mathrm{~b}$ and 4 ).

To trace the fine particle dispersion, sediment samples taken near and far from AMWDs were also observed. The sediments collected near AMWD4 (XS1) had an As concentration of $4575 \pm 79 \mathrm{mg} / \mathrm{kg}$, and XRD results established that these sediments were mainly composed of quartz and aluminosilicates ( $58 \%$ of the bulk). However, the results indicated that the remaining $42 \%$ was composed of gypsum ( $47 \%)$, K-jarosite (24\%), beudantite (16\%) (an As-Pb-bearing secondary mineral), and goethite (13\%). The presence of As-bearing IOH was observed in the SEM microphotographs of the XS1 stream sediment (Figure $8 \mathrm{c}$ ) and was likely related to precipitation or coprecipitation processes (or both) $[41,55,72]$. In addition, in XS1, it is possible to observe the drag of SMPs from AMWD4 to sediment streams through the physical erosion of fine particles $(\sim 80 \mu \mathrm{m})$ of scorodite (Figure 8d).

The XS2 stream sediment located $2.6 \mathrm{~km}$ downstream from AMWD4 contained $690 \pm 20 \mathrm{mg} / \mathrm{kg}$ As. The decrease in As concentration indicated a dilution process with respect to sample XS1. The XS2 stream sediments were mainly composed of the mineralogical phases of quartz and aluminosilicates ( $76 \%$ of the bulk). According to XRD results, it was possible to verify that the remaining $24 \%$ of the bulk consisted of carbonate $(60 \%)$, Jrs $(22 \%)$, and sarkinite $(18 \%)$ phases. At this site, the presence of fine particles $(<10 \mu \mathrm{m})$ of beudantite, ferricopiapite, and $\mathrm{IOH}$ (Figure 8e) could explain the migration of As from the dumps of mining residues by hydraulic flow [73].

The XS3 stream sediment, located $11.5 \mathrm{~km}$ downstream from AMWD4, is a fine particle accumulation zone. This sample presented an As concentration of $1970 \pm 71 \mathrm{mg} / \mathrm{kg}$, and the XRD results indicated the presence of As-bearing SMPs, such as beudantite and K-jarosite, produced by AMD (Figure 7). In addition, the SEM micrographs of this sample showed fine beudantite particles $(<10 \mu \mathrm{m})$ occluded in ferricopiapite, scorodite, and $\mathrm{IOH}$ mineral phases (Figure $8 \mathrm{f}, \mathrm{g}$ ). However, it is shown that, probably after hydric erosion processes, As-bearing fine particles (beudantite) are released, as they are no longer surrounded by ferricopiapite (Figure 8g,h). This fragmentation could be a consequence of either hydric erosion or abrasion in the accumulation zone. The presence of As-bearing fine particles in XS3 and XS4 could be attributed to migration in aqueous suspension or promoted by dragging due to the hydraulic flow. The XS4 sediment sample presented a predominance of Qz, K-Fe aluminosilicates, and carbonates, as well as a dilution in the As concentration up to $610 \pm 60 \mathrm{mg} / \mathrm{kg}$ (Figure 7), with respect to XS3. This last value could be associated with the dilution effect on the sediments of the Xichú Stream due to the incorporation of geological materials carried by the Guamuchil Stream. The XRD results for the stream sediments showed no evidence of the high concentrations of $\mathrm{Tl}$ and $\mathrm{Hg}$; however, the impact of these elements via the AMWDs should be further studied (Figures $3 a$ and 7).

Considering the formation of SMPs and their possible As migration from the AMWDs, the SI of the mineral phases of interest were calculated (Table 3). The SI for each aqueous samples showed a sequence of chemical stability as a function of their chemical and physicochemical conditions.

The presence of subsaturated secondary minerals was observed in the samples collected near the AMWD of the La Aurora mine (L1-L7), indicating that the minerals in these samples were under dissolution conditions and could have been supplying As that was adsorbed or coprecipitated, or both. It was determined that the L5, L2, L6, and L7 samples were oversaturated in goethite and lepidocrocite. The precipitation of these minerals would have controlled the mobility of As in the mine waste area (Figure S1). Asta et al. [72] determined that the concentration of As in areas contaminated by AMD was naturally attenuated by the formation of new mineral phases such as schwertmannite, K-Jrs and goethite, which play an important role in the removal of As through adsorption and coprecipitation processes. Fine particles of iron oxide, as well as $\mathrm{IOH}_{-} \mathrm{SO}_{4}{ }^{2-}$ precipitates, are dispersed downstream away from mine waste dumps by water flow. The range of SI values calculated for each aqueous sample (Table 3) supports the hypothesis that 
when As-bearing mineral phases (such as scorodite, beudantite, coquimbite, ferricopiapite, K-jarosite, adamite, segnitite, and guerinite) reach the El Ojo de Agua spring by hydric erosion, As is released via a mineral dissolution mechanism (Figure S2).

Table 3. Mineral phases present in the samples from the study area.

\begin{tabular}{|c|c|c|c|c|c|}
\hline \multirow[t]{2}{*}{ Abbreviation $^{1}$} & Name & \multirow[t]{2}{*}{ Chemical Formula } & \multicolumn{2}{|c|}{ Solid Sample } & \multirow[t]{2}{*}{ Index Saturation Range ${ }^{2}$} \\
\hline & Mineral Gangue & & AMWD & Sediments & \\
\hline Qz & Quartz & $\mathrm{SiO}_{2}$ & $\sqrt{ }$ & $\sqrt{ }$ & \\
\hline Als & Aluminosilicate & $\mathrm{K}\left(\mathrm{AlSi}_{3} \mathrm{O}_{8}\right)$ & $\sqrt{ }$ & $\sqrt{ }$ & \\
\hline Cal & Calcite & $\mathrm{CaCO}_{3}$ & & $\sqrt{ }$ & -0.8 to -1.2 \\
\hline \multicolumn{6}{|c|}{ Primary phases } \\
\hline $\mathrm{L}$ & Lautite & CuAsS & $\sqrt{ }$ & $\sqrt{ }$ & $(*)$ \\
\hline Ccp & Chalcopyrite & $\mathrm{CuFeS}_{2}$ & & $\sqrt{ }$ & $(*)$ \\
\hline Cct & Calcocite & $\mathrm{Cu}_{2} \mathrm{~S}$ & $\sqrt{ }$ & & $(*)$ \\
\hline $\mathrm{Sp}$ & Sphalerite & $\mathrm{ZnS}$ & Hypothetic & neral phase & $(*)$ \\
\hline Gtn & Gratonite & $\mathrm{PbS}_{2} \mathrm{As}_{2} \mathrm{~S}_{3}$ & $\sqrt{ }$ & & $(*)$ \\
\hline Py & Pyrite & $\mathrm{FeS}_{2}$ & $\sqrt{ }$ & & $(*)$ \\
\hline Rlg & Realgar & $\mathrm{As}_{4} \mathrm{~S}_{4}$ & $\sqrt{ }$ & $\sqrt{ }$ & $(*)$ \\
\hline Orp & Orpiment & $\mathrm{As}_{2} \mathrm{~S}_{3}$ & $\sqrt{ }$ & & $(*)$ \\
\hline Slf & Sulfur & S & $\sqrt{ }$ & $\sqrt{ }$ & $(*)$ \\
\hline \multicolumn{6}{|c|}{ Iron oxy-hydroxides } \\
\hline $\mathrm{He}$ & Hematite & $\mathrm{Fe}_{1.8} \mathrm{H}_{0.66} \mathrm{O}_{3}$ & $\sqrt{ }$ & $\sqrt{ }$ & 4.1 to -17.6 \\
\hline Gth & Goethite & $\mathrm{Fe}_{2} \mathrm{O}_{3} \cdot \mathrm{H}_{2} \mathrm{O}$ & $\sqrt{ }$ & $\sqrt{ }$ & 1.6 to -9.2 \\
\hline Lpd & Lepidocrocite & $\mathrm{Fe}^{+3} \mathrm{O}(\mathrm{OH})$ & $\sqrt{ }$ & & 2.8 to -10.7 \\
\hline Fhy & Ferrihydrite & $\mathrm{Fe}_{2}(\mathrm{OH})_{3} \cdot 0.5 \mathrm{H}_{2} \mathrm{O}$ & Hypothetic & neral phase & 1.3 to -12.3 \\
\hline \multicolumn{6}{|c|}{ Secondary mineral phases } \\
\hline Gy & Gypsum & $\mathrm{CaSO}_{4} \cdot 2 \mathrm{H}_{2} \mathrm{O}$ & $\sqrt{ }$ & $\sqrt{ }$ & -0.6 to -2.1 \\
\hline Scr & Scorodite & $\mathrm{FeAsO}_{4} \cdot 2 \mathrm{H}_{2} \mathrm{O}$ & $\sqrt{ }$ & $\sqrt{ }$ & -1.4 to -17.7 \\
\hline $\mathrm{Bdt}$ & Beudantite & $\mathrm{Pb}\left(\mathrm{Fe}_{2.5} \mathrm{Al}_{0.46}\right)\left(\mathrm{As}_{1.07} \mathrm{O}_{4}\right) \mathrm{SO}_{4}(\mathrm{OH})$ & )$_{6} \sqrt{ }$ & $\sqrt{ }$ & -0.2 to -44.2 \\
\hline $\mathrm{Pb}-J \mathrm{rs}$ & Plumbojarosite & $\left(\mathrm{Pb}_{0.43} \mathrm{~K}_{0.14}\right) \mathrm{Fe}_{3}\left(\mathrm{SO}_{4}\right)_{2}(\mathrm{OH})_{6}$ & $\sqrt{ }$ & $\sqrt{ }$ & \\
\hline K-Jrs & K-Jarosite & $\left(\mathrm{K}_{0.86}\left(\mathrm{H}_{3} \mathrm{O}\right)_{0.14}\right) \mathrm{Fe}_{3}\left(\mathrm{SO}_{4}\right)_{2}(\mathrm{OH})_{6}$ & $\sqrt{ }$ & $\sqrt{ }$ & -5 to 30.7 \\
\hline Adm & Adamite & $\mathrm{Zn}_{2}\left(\mathrm{AsO}_{4}\right)(\mathrm{OH})$ & $\sqrt{ }$ & & -5.5 to -22.9 \\
\hline Lnk & Lanarkite & $\mathrm{Pb}_{2}\left(\mathrm{SO}_{4}\right) \mathrm{O}$ & $\sqrt{ }$ & & -8.7 to -16.6 \\
\hline Bch & Brochantite & $\mathrm{Cu}_{4}\left(\mathrm{SO}_{4}\right)(\mathrm{OH})_{6}$ & $\sqrt{ }$ & & -6.9 to -30.1 \\
\hline Cld & Claudetite & $\mathrm{As}_{2} \mathrm{O}_{3}$ & $\sqrt{ }$ & & -10.5 to -27.4 \\
\hline Sgn & Segnetite & $\mathrm{PbFe}_{3}\left(\mathrm{AsO}_{4}\right)\left(\mathrm{AsO}_{3} \mathrm{OH}\right)(\mathrm{OH})_{6}$ & $\sqrt{ }$ & & -12.2 to -45.2 \\
\hline $\mathrm{Cqm}$ & Coquimbite & $\mathrm{Fe}_{1.54} \mathrm{Al}_{0.46}\left(\mathrm{SO}_{4}\right)_{3} \cdot 9 \mathrm{H}_{2} \mathrm{O}$ & $\sqrt{ }$ & & -28.1 to -35.1 \\
\hline Grn & Guerinite & $\mathrm{Ca}_{5}\left(\mathrm{AsO}_{4}\right)_{2}\left(\mathrm{AsO}_{3}(\mathrm{OH})\right)\left(\mathrm{H}_{2} \mathrm{O}\right)_{4}$ & $\sqrt{ }$ & $\sqrt{ }$ & -17.8 to -39.3 \\
\hline Skn & Sarkinite & $\mathrm{Mn}_{2} \mathrm{AsO}_{4}(\mathrm{OH})$ & $\sqrt{ }$ & $\sqrt{ }$ & -26.5 to -47.8 \\
\hline Fcpp & Ferricopiapite & $\mathrm{Fe}_{4.67}\left(\mathrm{SO}_{4}\right)_{6}(\mathrm{OH})_{2} \cdot 20 \mathrm{H}_{2} \mathrm{O}$ & $\sqrt{ }$ & & -34 to -46 \\
\hline
\end{tabular}

${ }^{1}$-Mineral abbreviation was assigned following Whitney and Evans [74]. ${ }^{2}$-Index saturation range was determined with PHREEQC, using the values in Table 2 for each aqueous sample. $\sqrt{ }-$ Mineral phase identified in AMWD and sediments by XRD. $\left({ }^{*}\right)-$ Mineral phase not modeled because hydrogen sulfide concentrations in solution were not determined.

\section{Conclusions}

In this study, the qualities of different bodies of water in the XMD were determined, and among other pollutants, the presence of $\mathrm{As}, \mathrm{Hg}$, and $\mathrm{Tl}$ was measured, respectively. Based on the chemical and physicochemical parameters measured and, mainly through the PCA statistical tool, a water quality classification of the different collected samples was proposed, resulting in four water samples classified as uncontaminated (W1, W2, EG, and ES), three as slightly-moderately contaminated (R1, CA, and GA), and the rest of the samples classified as highly-extremely contaminated, including a potential source of drinking water in the region, i.e., the El Ojo de Agua spring.

Additionally, the isotopic compositions of $\delta^{18} \mathrm{O}_{\text {sulfate }}$ and $\delta^{34} \mathrm{~S}_{\text {sulfate }}$ allowed the identification of three processes of sulfate fluxes (input and output fluxes) in the study area 
that correspond to (1) the oxidation of mineral sulfides; (2) the precipitation of secondary sulfate mineral phases produced by AMWD weathering; and (3) sulfate dissolution from evaporites contained in the El Abra Formation. In fact, the isotopic signature of $\delta^{18} \mathrm{O}_{\text {sulfate }}$ and $\delta^{34} S_{\text {sulfate }}$ made it possible to establish that the origin of sulfates in the Santa Maria River and the El Ojo de Agua spring is similar and is associated with the dissolution of evaporites.

PCA and Pearson correlations made it possible to establish that the main source of As contamination in the study area is related to the weathering products of AMWDs. These tailings deposits, without coverings, are exposed to environmental conditions, generating AMD that percolates through tailings, promoting the formation of new As-bearing secondary phases. Hence, the impact of the tailings on the water bodies was associated with the physical migration promoted by the hydraulic drag of these secondary phases. The secondary phases, in the form of fragmented particles, decrease in size while they are dragged, either by erosion or by abrasion processes (or by both) during their migration. They also undergo fracturing processes and release fine particles with high arsenic content. This was evidenced through chemical analyses performed with scanning electron microscopyenergy dispersive X-ray spectrometry (SEM-EDS) on sediment samples collected along the stream channels that flow into the El Ojo de Agua spring. It was not possible to identify any fine particle carriers of $\mathrm{Tl}$ and $\mathrm{Hg}$, so it is assumed that the presence of these elements is related to other processes that favor their entry to the spring. From the PCA analyses and Pearson's correlations, it is hypothesized that the fraction of thallium present in the El Ojo de Agua spring could be related to the weathering processes of AMWDs. However, the presence of $\mathrm{Tl}$ and $\mathrm{Hg}$ in the springs in the Palomas reference zone suggests that an important contribution to consider could be the dissolution of these elements from igneous rocks in the study area when rainwater interacts with them and then percolates through the limestone of the El Abra Formation, which, however, needs further review.

Finally, the results suggest that the presence of sulfates in the spring is of natural origin - the presence of As is related to the dissolution of fine particles of the secondary phases (resulting from precipitation from mine waste leachates) that carry this element when they enter the body of water, and it is not yet possible to establish reliably whether, in the El Ojo de Agua spring, the presence of $\mathrm{Tl}$ and $\mathrm{Hg}$ is of natural or anthropogenic origin.

Water contamination by $\mathrm{Tl}$ and $\mathrm{Hg}$ is evidenced in this work only as a preliminary finding. It is necessary to carry out in-depth studies that allow us to reliably explain their presence; however, the authors of this work consider it important to highlight this result, due to public interest in the impacts that these elements could have on vulnerable communities in the region. This is important when the geographical location is difficult to access and the infrastructure to acquire other water resources for human consumption is lacking.

Supplementary Materials: The following are available online at https://www.mdpi.com/article/ 10.3390/toxics9110307/s1, Figure S1: Climatograph of the study area based on the average of monthly data of the period 1951-2015 [30], Figure S2: Saturation index estimation of the main mineral phases identified by XRD in samples from AMDW4 when they are in contact with the physicochemical quality of leachate, river, well, and spring samples using PHREEQCI (2.15 software), Table S1: Pearson's correlation coefficient between the physicochemical parameters and ions quantified in the leachates, river, and spring water samples in the study area, Table S2: Eigenvectors from principal component analysis for the different types of water samples collected in the study area (with transformed variables to square root values), Table S3: Water quality classification considering the PCA values calculated with physicochemical parameters and chemical compositions of aqueous solution samples, Table S4: Proposed reactions involved in the oxidation of primary sulfide minerals and precipitation or dissolution reactions that produce the SMPs that were identified by XRD in the waste and sediment samples collected from AMDW4 [7,14,51], Table S5: SEM-EDS analysis of waste and stream sediment samples: AMWD (a,b), XS1 (c,d), XS2 (e), XS3 (f,g), and XS4 (h). SMPs were assigned by mass balance reconstruction based on chemical composition. 
Author Contributions: Conceptualization, R.B.-G.; formal analysis, V.M.E.-E., Y.R.R.-A. and R.B.-G.; writing-original draft preparation, V.M.E.-E.; writing-review and editing, investigation and methodology, V.M.E.-E., Y.R.R.-A., I.M.-A., L.C.-Y. and R.B.-G.; resources, I.L. and R.B.-G.; project administration and supervision, R.B.-G.; funding acquisition, I.L. All authors have read and agreed to the published version of the manuscript.

Funding: This work was supported by National Council of Science and Technology [FORDECYT 190966] and [Scholarship CONACYT 414060]. This research did not receive additional grants from funding agencies in the public, commercial, or not-for-profit sectors.

Data Availability Statement: All supporting data have been included in this study and are available from the corresponding authors upon request.

Acknowledgments: The authors thank R.L. Tovar and I. Lopez-Acosta for their analytical support.

Conflicts of Interest: The authors declare no conflict of interest. The funders had no role in the design of the study; in the collection, analyses, or interpretation of data; in the writing of the manuscript, or in the decision to publish the results.

\section{References}

1. Lottermoser, B.G. Mine Wastes: Characterization, Treatment and Environmental Impacts, 3rd ed.; Springer: Berlin, Germany, 2010; pp. 1-334. [CrossRef]

2. Bini, C. Environmental Impact of Abandoned Mine Waste: A Review, 1st ed.; Nova Science Publishers: New York, NY, USA, 2012; pp. 1-92.

3. United State Environmental Protection Agency (USEPA). Available online: https://www.epa.gov/superfund/abandoned-minelands-basic-information-0 (accessed on 7 August 2021).

4. Hammarstrom, J.M.; Smith, K.S. Geochemical and mineralogic characterization of solids and their effects on waters in metal mining environments. Chapter, B. In Progress on Geoenvironmental Models for Selected Mineral Deposits Types, 1st ed.; Seal, R.R., Foley, N.K., Eds.; U.S. Geological Survey: Lincoln, OR, USA, 2002; pp. 8-54.

5. Hudson, K.; Jamieson, H.; Lottermoser, B. Mine wastes: Past, present and future. Elements 2011, 7, 375-380. [CrossRef]

6. Plumlee, G.S. The environmental geology of mineral deposits. In Reviews in Economic Geology, 1st ed.; Plumlee, G.S., Logsdon, M.J., Eds.; U.S. Geology Survey: Littleton, CO, USA, 1999; Volume 6A, pp. 71-116.

7. Blowes, D.W.; Ptacek, C.J.; Jambor, J.L.; Weisener, C.G.; Paktunc, D.; Gould, W.D.; Johnson, D.B. The geochemistry of acid mine drainage. In Treatise on Geochemistry, 2nd ed.; Lollar, B.S., Holland, H.D., Turekian, K.K., Eds.; Elsevier-Pergamon: Oxford, UK, 2014; Volume 11, pp. 131-190. [CrossRef]

8. Nordstrom, D.K. Hydrogeochemical processes governing the origin, transport and fate of major and trace elements from mine wastes and mineralized rock to surface waters. Appl. Geochem. 2011, 26, 1777-1791. [CrossRef]

9. Bundschuh, J.; Jean, J.S.; Liu, C.; López, D.; Armienta, M.; Guilherme, L.R.; Toujaguez, R. One century of arsenic exposure in Latin America: A review of history and occurrence from 14 countries. Sci. Total. Environ. 2012, 429, 2-35. [CrossRef]

10. Nordstrom, D.K.; Blowes, D.W.; Ptacek, C.J. Hydrogeochemistry and microbiology of mine drainage: An update. Appl. Geochem. 2015, 57, 3-16. [CrossRef]

11. Ramos-Arroyo, Y.R.; Guerrero-Aguilar, A.; Cano-Rodriguez, I.; Gutierrez-Valtierra, M.; Miranda, R. Arsenic Liberation from Mine Wastes Derived of Skarn Deposits at Sierra Madre Oriental, México. Procedia Earth Planet. Sci. 2017, 17, 833-836. [CrossRef]

12. Bigham, J.M.; Schwertmann, U.; Traina, S.J.; Winland, R.L.; Wolf, M. Schwertmannite and the chemical modeling of iron in acid sulfate waters. Geochim. Cosmochim. AC 1996, 60, 2111-2121. [CrossRef]

13. Cornell, R.M.; Schwertmann, U. The Iron Oxides. Structure, Properties, Reactions, Occurrences and Uses; Wiley-VCH Verlag GmbH and Co. KGaA: Weinheim, Germany, 2003; pp. 1-664. [CrossRef]

14. Dold, B. Basic concepts in environmental geochemistry of sulfidic mine-waste management. In Waste Management, 1st ed.; Sunil, K.E., Ed.; IntechOpen: Rijeka, Croatia, 2010; Volume 1, pp. 173-198. [CrossRef]

15. Hammarstrom, J.M.; Seal, R.R.; Meierb, A.L.; Kornfeld, J.M. Secondary sulfate minerals associated with acid drainage in the eastern US: Recycling of metals and acidity in surficial environments. Chem. Geol. 2005, 215, 407-431. [CrossRef]

16. Armienta, M.A.; Villaseñor, G.; Rodríguez, R.; Ongley, L.K.; Mango, H. The role of arsenic bearing rocks in groundwater pollution at Zimapán Valley, México. Environ. Geol. 2011, 40, 571-581. [CrossRef]

17. Armienta, M.A.; Rodriguez, R.; Aguayo, A.; Ceniceros, N.; Villaseñor, G.; Cruz, O. Arsenic contamination of groundwater at Zimapán, México. Hydrogeol. J. 1997, 5, 39-46. [CrossRef]

18. Mandal, B.; Suzuki, K. Arsenic round the world: A review. Talanta 2002, 58, 201-235. [CrossRef]

19. Verma, S.; Mukherjee, A.; Mahanta, C.; Choudhury, R.; Mitra, K. Influence of geology on groundwater-sediment interactions in arsenic enriched tectono-morphic aquifers of the Himalayan Brahmaputra river basin. J. Hydrol. 2016, 540, 176-195. [CrossRef]

20. Mohan, D.; Pittman, C.U. Arsenic removal from water/wastewater using adsorbents- a critical review. J. Hazard. Mater. 2007, 142, 1-53. [CrossRef] 
21. Smedley, P.L.; Kinniburgh, D.G. A review of the source, behaviour and distribution of arsenic in natural waters. Appl. Geochem. 2002, 17, 517-568. [CrossRef]

22. Fleischer, M. Summary of the literature on the inorganic geochemistry of mercury. In Mercury in the Environment Geological Survey Professional Paper 713, 1st ed.; Hickel, W.J., Pecora, W.T., Eds.; U.S Geological survey: Washington, DC, USA, 1970; Volume 1, pp. 6-13.

23. Hammarstrom, J.M. Environmental Geochemistry of Skarn and Polymetallic Carbonate-replacement deposit models. Chapter, H. In Progress on Geoenvironmental Models for Selected Mineral Deposits Types, 1st ed.; Seal, R.R., Foley, N.K., Eds.; U.S. Geological Survey: Lincoln, OR, USA, 2002; pp. 115-142.

24. Wershaw, R.L. Sources and behavior of mercury in surface waters. In Mercury in the Environment Geological Survey Professional Paper 713, 1st ed.; Hickel, W.J., Pecora, W.T., Eds.; U.S Geological survey: Washington, DC, USA, 1970; Volume 1, pp. $29-34$.

25. Campanella, B.; Onor, M.; D’Ulivo, A.; Giannecchini, R.; D'Orazio, M.; Petrini, R.; Bramanti, E. Human exposure to thallium through tap water: A study from Valdicastello Carducci and Pietrasanta (northern Tuscany, Italy). Sci. Total Environ. 2016, 1, 548-549. [CrossRef]

26. D'Orazio, M.; Biagioni, C.; Dini, A.; Vezzoni, S. Thallium-rich pyrite ores from the Apuan Alps, Tuscany, Italy: Constraints for their origin and environmental concerns. Miner. Deposita 2017, 52, 687-707. [CrossRef]

27. Ramos-Arroyo, Y.R.; Arredondo, J.C.; Chávez, V.M.; Pérez, I.; Olvera, Á. Descripción del potencial de aprovechamiento hídrico y de riesgos hidrológicos en el municipio de Xichú, NE del estado de Guanajuato. Acta Universitaria 2016, 26, 7-21. [CrossRef]

28. Tello-Vázquez, J. Xichú. Colección de Monografías Municipales de Guanajuato, 1st ed.; Dávalos Hermanos, S.A., Ed.; Gobierno del Estado de Guanajuato: Leon, Mexico, 2010; pp. 1-206.

29. Kottek, M.; Grieser, J.; Beck, C.; Rudolf, B.; Rubel, F. World map of the Köppen-Geiger climate classification updated. Meteorol. Z. 2006, 15, 259-263. [CrossRef]

30. Comisión Nacional del Agua (CONAGUA) Datos de la Estación Meteorologica 11083-Inventarios de Registro por Década Año. Available online: https://smn.conagua.gob.mx/es/climatologia/informacion-climatologica/informacion-estadisticaclimatologica (accessed on 16 November 2021).

31. Martínez-Arredondo, J.C.; Ortega-Chávez, V.M.; Ramos-Arroyo, Y.R. Regional climatic indices for the Sierra Gorda of Guanajuato. Acta Universitaria 2013, 23, 10-25. [CrossRef]

32. Arredondo-Mendoza, J.A.; Rivera-Venegas, I.; Servicios Geológicos Mineros, S.A de C.V. Carta Geológico-Minera Xichú F14-C36, Escala 1:50,000, Estado de Guanajuato, 1st ed.; Servicio Geológico Mexicano: Pachuca, Mexico, 2001.

33. Cárdenas-Vargas, J.; Yañez-Mondragon, C.F.; Consejo de Recursos Minerales. Monografía Geológico-Minera del Estado de Guanajuato, 1st ed.; Secretaria de Energía, Minas e Industria Paraestatal, Subsecretaria de Minas e Industria Básica: Pachuca, Mexico, 1992.

34. González-Ramos, A.; Rodríguez-Moreno, R. Informe de la Carta Geológico-Minera El Carricillo F14-C37 Escala 1:50 000 Estados de Guanajuato, Querétaro y San Luis Potosí Guanajuato, 1st ed.; Servicios Geológicos Mineros: Pachuca, Mexico, 2000.

35. World Health Organization (WHO). Guidelines for Drinking-Water Quality, 4th ed.; World Health Organization: Geneva, Switzerland, 2017.

36. Diario Oficial de la Federación (DOF). Available online: http: / / www.dof.gob.mx/nota_detalle.php? codigo=2063863\&fecha=22/1 $1 / 2000$ (accessed on 8 October 2021).

37. United State Environmental Protection Agency (USEPA). Ambient Water Quality Criteria for Thallium EPA-440/5-80-074, 1st ed.; Office of Water Regulations and Standards Criteria and Standard Division: Springfield, IL, USA, 1980; pp. 1-71.

38. Martínez, M.C. Geometría estructural de la sierra madre oriental, entre Peñamiller y Jalpan, estado de Querétaro. Revista Mexicana Ciencias Geológicas 1990, 9, 62-70.

39. Comisión Nacional del Agua (CONAGUA). Available online: https://www.gob.mx/cms/uploads/attachment/file/103004 /DR_1101.pdf (accessed on 8 October 2021).

40. Torres-Rivera, S.; Ramos-Leal, J.A.; Moran-Ramírez, J.; Torres-Hernández, J.R.; Padilla-Sánchez, L.; Carranco-Lozada, S.E.; García-Arreola, M.E. Hydrogeochemical characterization and quantification of the groundwater mixture in a hydrogeological basin of the middle zone of San Luis Potosí. Geophy. Int. 2019, 58, 247-258. [CrossRef]

41. Carrillo-Chávez, A.; Salas-Megchún, E.; Levresse, G.; Múñoz-Torres, C.; Pérez-Arvizu, O.; Gerke, T. Geochemistry and mineralogy of mine-waste material from a "skarn-type" deposit in central Mexico: Modeling geochemical controls of metal in the surface environment. J. Geochem. Explor. 2014, 144, 28-36. [CrossRef]

42. Loredo-Portales, R.; Castillo-Michel, H.; Aquilanti, G.; De La Rosa-Alvarez, G.; Rocha-Amador, D.O.M.; Vogel-Mikus, K.; Kump, P.; Cruz-Jimenez, G. Synchrotron based study of as mobility and speciation in tailings from a mining site in Mexico. J. Environ. Chem. Eng. 2017, 5, 1140-1149. [CrossRef]

43. Miranda-Gasca, M.A. Estudio geológico-geoquímico regional del área de Xichú. GTO. B. Soc. Geol. Mex. 1978, 39, 101-106. [CrossRef]

44. Sánchez-González, J.A. Inventario Físico de Los Recursos Minerales del Municipio de Xichú, GTO, 1st ed.; Consejo de Recursos Minerales-Dirección de Minas de Guanajuato: Pachuca, Mexico, 2003; pp. 1-49.

45. Wasteneys, G.M. Minas Aurora y Anexas Xichu, Gto. Archivo Técnico Servicio Geológico Mexicano 1922, 1, 1-19.

46. Wolkersdorfer, C.; Nordstrom, D.K.; Beckie, R.D.; Cicerone, D.S.; Elliot, T.; Edraki, M.; Valente, T.; Alves-França, S.C.; Kumar, P.; Oyarzún-Lucero, R.A.; et al. Guidance for the integrated use of hydrological, geochemical, and isotopic tools in mining operations. Mine Water Environ. 2020, 39, 204-228. [CrossRef] 
47. Eaton, A.D.; Clesceri, L.S.; Rice, W.E.; Greenberg, A.E. Standard Methods for the Examination of Water and Wastewater, 21st ed.; American Public Health Association (APHA): Washington, DC, USA, 2005.

48. Gray, N.F. Field assessment of acid mine drainage contamination in surface and ground water. Environ. Geol. 1996, 27, 358-361. [CrossRef]

49. Ball, J.W.; Nordstrom, D.K. WATEQ4F-User's Manual with Revised Thermodynamic Data Base and Test Cases for Calculating Speciation of Major, Trace and Redox Elements in Natural Waters; Open-File Report; USGS Publications Warehouse: Washington, DC, USA, 1991; pp. 90-129. [CrossRef]

50. Nordstrom, D.K.; McCleskey, R.B.; Ball, J.W. Sulfur geochemistry of hydrothermal waters in Yellowstone National Park: IV Acid-Sulfate waters. Appl. Geochem. 2009, 24, 191-207. [CrossRef]

51. Blanc, P.; Lassina, A.; Piantone, P.; Azaroual, M.; Jacquemet, N.; Fabbri, A.; Gaucherd, E.C. Thermoddem: A geochemical database focused on low temperature water/rock interactions and waste materials. Appl. Geochem. 2012, 27, 2107-2116. [CrossRef]

52. Liao, Z.; Chen, Y.; Ma, J.; Islam, M.; Weng, L.; Li, Y. Cd, Cu, and Zn Accumulations Caused by Long-Term Fertilization in Greenhouse Soils and Their Potential Risk Assessment. Int. J. Environ. Res. Public Health 2019, 16, 2805. [CrossRef] [PubMed]

53. Zhiyuan, W.; Dengfeng, W.; Huiping, Z.; Zhiping, Q.I. Assessment of soil heavy metal pollution with principal component analysis and geoaccumulation index. Procedia Environ. Sci. 2011, 10, 1946-1952. [CrossRef]

54. Martin, C.W. Heavy metal trends in floodplain sediments and valley fill, River Lahn. Germany. Catena 2000, 39, 53-68. [CrossRef]

55. Campbell, K.M.; Nordstrom, D.K. Arsenic speciation and sorption in natural environments. Rev. Mineral. Geochem. 2014, 79, 185-216. [CrossRef]

56. Domagalski, J. Mercury and methylmercury in water and sediment of the Sacramento River Basin, California. Appl. Geochem. 2001, 16, 1667-1691. [CrossRef]

57. Anawar, M.H. Sustainable rehabilitation of mining waste and acid mine drainage using geochemistry, mine type, mineralogy, texture, ore extraction and climate knowledge. J. Environ. Manag. 2015, 158, 111-121. [CrossRef] [PubMed]

58. Tadesse, I.; Green, F.B.; Puhakka, J.A. Seasonal and diurnal variations of temperature, $\mathrm{pH}$ and dissolved oxygen in advanced integrated wastewater pond system ${ }^{\circledR}$ treating tannery effluent. Water Res. 2004, 38, 645-654. [CrossRef]

59. Tanner, C.C.; Craggs, R.J.; Sukias, J.P.S.; Park, J.B.K. Comparison of maturation ponds and constructed wetlands as the final stage of an advanced pond system. Water Sci. Technol. 2005, 51, 307-314. [CrossRef]

60. Hindersmann, I.; Mansfeldt, T. Trace element solubility in a multimetal-contaminated soil as affected by redox conditions. Water Air Soil Pollut. 2014, 225, 2158. [CrossRef]

61. Montes-Avila, I.; Espinosa-Serrano, E.; Castro-Larragoitia, J.; Lázaro, I.; Cardona, A. Chemical mobility of inorganic elements in stream sediments of a semiarid zone impacted by ancient mine residues. Appl. Geochem. 2019, 100, 8-21. [CrossRef]

62. Puigdomenech, I.; Colas, E.; Grive, M.; Campos, I.; García, D. A tool to draw chemical equilibrium diagrams using SIT: Applications to geochemical systems and radionuclide solubility. Mater. Res. Soc. Symp. Proc. 2014, 1665, 111-116. [CrossRef]

63. Segerstrom, K. Geology of the Bernal-Jalpan area, Estado de Querétaro, México. Bull. U.S. Geol. Surv. 1961, 1104, 9-86. [CrossRef]

64. Martínez-Trinidad, S.; Hernández-Silva, G.; Ramírez-Islas, M.E.; Martínez-Reyes, J.; Solorio-Murguia, G.; Solís-Valdez, S.; GarcíaMartínez, R. Total mercury in terrestrial systems (air-soil-plant-water) at the mining region of San Joaquín, Queretaro, Mexico. Geophy. Int. 2013, 52, 43-58. [CrossRef]

65. Brenot, A.; Carignan, J.; France-Lanord, C.; Benoît, M. Geological and land use control on $\delta 34 \mathrm{~S}$ and $\delta 18 \mathrm{O}$ of river dissolved sulfate: The Moselle river basin, France. Chem. Geol. 2007, 244, 25-41. [CrossRef]

66. Dold, B.; Spangenber, J. Sulfur Speciation and Stable Isotope Trends of Water-Soluble Sulfates in Mine Tailings Profiles. Environ. Sci. Tech. 2005, 39, 5650-5656. [CrossRef]

67. Dótor-Almazán, A.; Armienta-Hernández, M.A.; Árcega-Cabrera, F.; Talavera-Mendoza, O. Procesos de transporte de arsénico y metales en aguas superficiales del distrito minero de Taxco, México: Aplicación de isótopos estables. Hidrobiológica 2014, 24, 245-256.

68. Otero, N.; Soler, A.; Canals, À. Controls of $\delta^{34} \mathrm{~S}$ and $\delta^{18} \mathrm{O}$ in dissolved sulphate: Learning from a detailed survey in the Llobregat River (Spain). Appl. Geochem. 2008, 23, 1166-1185. [CrossRef]

69. Claypool, G.E.; Holser, W.T.; Kaplan, I.R.; Sakai, H.; Zak, I. The age curve of sulfur and oxygen isotopes in marine sulfates and their mutual interpretation. Chem. Geol. 1980, 28, 199-260. [CrossRef]

70. Basáñez-Loyola, M.A.; Fernández-Turner, R.; Rosales-Domínguez, C. Cretaceous Platform of Valles-San Luis Potosi, Northeastern Central Mexico. In Cretaceous Carbonate Platforms, 1st ed.; Toni-Simo, J.A., Scott, R.W., Masse, J.P., Eds.; American Association of Petroleum Geologists B: Tulsa, OK, USA, 1993; Volume 1, pp. 51-59.

71. Dill, H.G. Geogene and anthropogenic controls on the mineralogy and geochemistry of modern alluvial-(fluvial) gold placer deposits in man-made landscapes in France, Switzerland and Germany. J. Geochem. Explor. 2008, 99, 29-60. [CrossRef]

72. Asta, M.P.; Cama, J.; Martínez., M.; Giménez, J. Arsenic removal by goethite and jarosite in acidic conditions and its environmental implications. J. Hazard. Mater. 2009, 171, 965-972. [CrossRef] [PubMed]

73. Rochette, E.A.; Li, G.C.; Fendorf, S.E. Stability of arsenate minerals in soil under biotically generated reducing conditions. Soil Sci. Soc. Am. J. 1998, 62, 1530-1537. [CrossRef]

74. Whitney, D.L.; Evans, B.W. Abbreviations for names of rock-forming minerals. Am. Mineral. 2010, 95, 185-187. [CrossRef] 